\title{
Prostaglandins and mechanisms of preterm birth
}

\author{
John R. G. Challis ${ }^{1}$, Deborah M. Sloboda ${ }^{1,3}$, Nadia Alfaidy ${ }^{1}$, \\ Steven J. Lye' ${ }^{1}$, William Gibb¹,2, Fal A. Patel ${ }^{1}$, \\ Wendy L. Whittle ${ }^{1}$ and John P. Newnham ${ }^{3}$ \\ ${ }^{1}$ Departments of Physiology and Obstetrics and Gynaecology, CIHR Group in Fetal and \\ Neonatal Health and Development, CIHR Institute of Human Development, Child and Youth \\ Health, University of Toronto, Medical Sciences Building, Suite 3368, Toronto M5S 1A8, \\ Canada; ${ }^{2}$ Department of Molecular Medicine, University of Ottawa, Ottawa K1 H 8L6, \\ Canada; and ${ }^{3}$ Department of Obstetrics and Gynaecology, University of Western Australia, \\ Subiaco, 6008, Australia
}

\begin{abstract}
Increased uterine contractility at term and preterm results first from activation and then stimulation of the myometrium. Activation can be provoked by mechanical stretch of the uterus, and by an endocrine pathway resulting from increased activity of the fetal hypothalamic-pituitary-adrenal axis. In sheep fetuses, increased cortisol output during pregnancy regulates expression of prostaglandin synthase type 2 (PGHS-2) in the placenta in an oestrogen-independent manner, resulting in increased concentrations of prostaglandin $E_{2}\left(P_{G E}\right)$ in the fetal circulation. Later increases in maternal uterine expression of PGHS-2 require increases in oestrogen and lead to increased concentrations of $\mathrm{PGF}_{2 \alpha}$ in the maternal circulation. Thus, regulation of PGHS-2 at term is differentially controlled in fetal (trophoblast) and maternal (uterine epithelium) tissue. This difference may reflect expression of glucocorticoid receptor but not oestrogen receptor (ER) in placental trophoblast cells. In women, cortisol also contributes to increased prostaglandin production in fetal tissues through upregulation of PGHS-2 (amnion and chorion) and downregulation of $15-\mathrm{OH}$ prostaglandin dehydrogenase ( $\mathrm{PGDH}$; chorion trophoblasts). The effect of cortisol on expression of $\mathrm{PGDH}$ in the chorion reverses a tonic stimulatory effect of progesterone, potentially through a paracrine or autocrine action. In membranes, cortisol may be derived from cortisone through activity of $11 \beta$-hydroxysteroid dehydrogenase (11 $\beta$-HSD) type 1 , in addition to secretion from the maternal or fetal adrenal glands. In placenta, $11 \beta$-HSD-2 oxidase activity predominates and expression of this enzyme is reduced with hypoxaemia and in placentae from pre-eclamptic pregnancies. In these circumstances, increased concentrations of maternal cortisol may cross into the fetal compartment, contributing to growth restriction and programming later life disease.
\end{abstract}

Preterm birth (birth before week 37 of gestation) occurs in approximately $5-10 \%$ of all pregnancies. This value may be higher in certain population groups and has not decreased over the past 20-30 years. Although some preterm births may be elective, approximately $30 \%$ occur in association with an underlying infectious process, and about 50\% are idiopathic preterm births of unknown cause. Preterm birth is associated with $70 \%$ of neonatal deaths, and up to $75 \%$ of neonatal morbidity. Infants born preterm have an increased incidence of blindness, deafness, cerebral palsy, neurological disorders and pulmonary disorders (Morrison, 1990; Copper et al., 1993; Lopez-Bernal et al., 1993; Lumley, 1993; Stubblefield, 1993; Villar et al., 1994). All of these

Email: j.challis@utoronto.ca risks are associated with increased health care costs (estimated at around \$8 billion annually in the USA) and great emotional burdens for the family. Spontaneous preterm labour affects both developed and underdeveloped countries and its prevention is a major aim of modern obstetrics (Creasy, 1991). Established risk factors for preterm labour include previous low birth weight or preterm delivery, multiple second trimester abortions, multiple gestations, placental anomalies, cervical and uterine anomalies, gestational bleeding, in vitro fertilization pregnancy, hydramnios, infection, cigarette smoking, single marital status, low socio-economic class and black race (Creasy and Gummer, 1980; Mercer et al., 1996). At present, there are no effective diagnostic indicators of preterm birth, and there are no effective treatments for this condition. Thus, the 


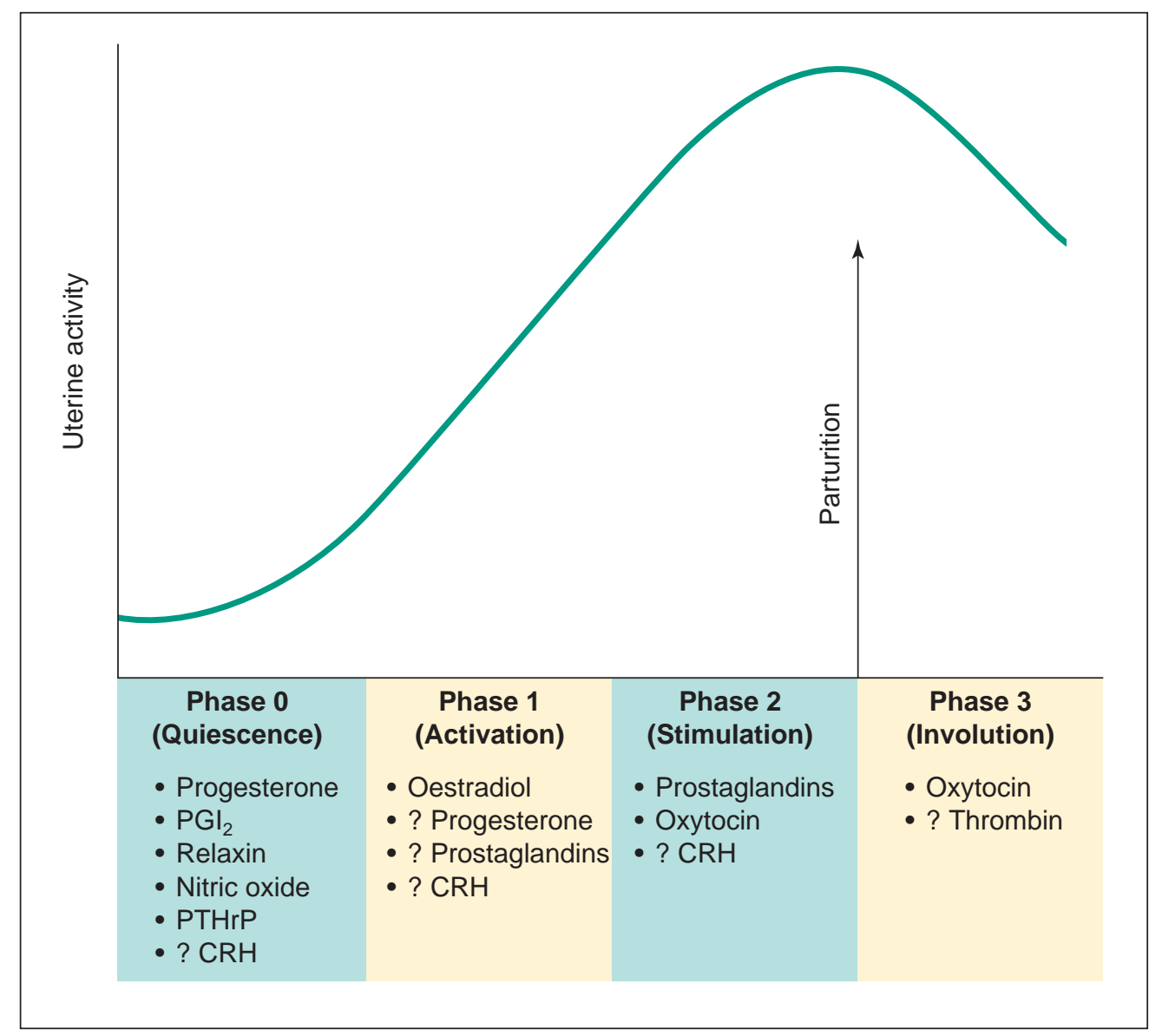

Fig. 1. Phases of uterine activity. A listing of the various agents involved during quiescence (phase 0), activation (phase 1), stimulation (phase 2) and involution (phase 3) of the uterus during pregnancy are represented. $\mathrm{PGI}_{2}$ : prostacyclin; PTHrP: parathyroid hormone related peptide; and CRH: corticotrophinreleasing hormone. (Adapted from Challis and Gibb, 1996.)

focus of current research is to understand the underlying biochemistry of the birth process, and to use that understanding to develop better diagnostic indicators, and improve methods of therapeutic management. This strategy would minimize inappropriate use of maternal glucocorticoids in women with threatened preterm labour.

\section{Phases of parturition}

Uterine contractility during pregnancy and parturition can be divided into at least four distinct phases (Lye et al., 1998; Challis et al., 2000) (Fig. 1). In phase 0 (pregnancy), the uterus is maintained in a relatively quiescent state through the separate or combined autocrine-paracrine actions of inhibitors such as progesterone, prostacyclin $\left(\mathrm{PGI}_{2}\right)$, relaxin, parathyroid hormone-related peptide (PTHrP), calcitonin gene-related peptide, adrenomedullin, vasoactive intestinal peptide, nitric oxide, and corticotrophin-releasing hormone $(\mathrm{CRH})$, which may both inhibit and stimulate uterine contractility (Challis et al., 2000). The diminished production of one or more of these agents during late gestation may lead to preterm or term uterine activity, whereas administration of these compounds or their analogues may help maintain uterine quiescence. These agents act in different ways but, in general, result in increased intracellular concentrations of cyclic adenosine monophosphate (cAMP) or cyclic guanosine monophosphate (cGMP). These nucleotides inhibit intracellular calcium release and reduce the activity of myosin light chain kinase (MLCK), which is required for shortening of the myofilaments. Several current strategies for managing preterm labour are directed at increasing intracellular CAMP and reducing the availability of calcium. Phase 1 of parturition is associated with activation of uterine function, wherein mechanical stretch or uterotrophic priming leads to upregulation of a cassette of genes required for contractions. These contraction-associated proteins (CAPs) include connexin43 (Cx43, a key component of gap junctions), agonist receptors (prostaglandins (PGs) and oxytocin), and proteins encoding ion channels. In phase 2 of parturition, the uterus can then be stimulated by utero- 
tonins including PGs, oxytocin, and $\mathrm{CRH}$. Phase 3 of parturition includes uterine involution after delivery of the fetus and placenta, and has been attributed primarily to the effects of oxytocin. The initiation of parturition may be defined as the transition from phase 0 (quiescence) to phase 1 (activation) during which there is a release from the mechanisms maintaining uterine quiescence throughout pregnancy and a recruitment of factors promoting uterine activity, including biomechanical factors such as uterine stretch and tension caused by the fully grown fetus.

It is clear that activation of myometrial function (phase 1) is driven by the fetal genotype, and effected through two separate but interdependent pathways (Lye et al., 1998). One pathway involves activation of the fetal hypothalamicpituitary-adrenal (HPA) axis. The second pathway involves mechanical distension of the uterus, leading to stretchrelated upregulation of CAP gene expression.

\section{Activation of fetal hypothalamic-pituitary-adrenal axis}

Maturation of fetal HPA function during late pregnancy occurs in most mammals, including primates (Liggins and Thorburn, 1994; Lye et al., 1998; Challis et al., 2000). Extensive studies in sheep fetuses have shown increased expression of CRH mRNA in parvocellular neurones of the paraventricular nucleus of the hypothalamus and of proopiomelanocortin (POMC) mRNA in the pars distalis of the fetal pituitary in late pregnancy. These changes correlate with increased concentrations of adrenocorticotrophic hormone $\left(\mathrm{ACTH}_{1-39}\right)$ in the fetal circulation. ACTH acts on the fetal adrenal gland to increase expression of key enzymes required for cortisol production (especially $\mathrm{P} 4 \mathrm{SO}_{\mathrm{C} 17}$ ), and to upregulate $\mathrm{ACTH}$ receptors in the fetal adrenal cortex. This mechanism allows enhanced binding and coupling to adenylate cyclase, resulting in increased sensitivity of the fetal adrenal gland to further stimulation by ACTH.

Activation of the fetal HPA axis occurs in the presence of an adverse intrauterine environment, for example with compromised uteroplacental blood flow or conditions of fetal hypoxaemia. Sheep fetuses made transiently hypoxaemic had increased concentrations of hypothalamic $\mathrm{CRH}$ mRNA and pituitary POMC mRNA (Lye et al., 1998). In late gestation, hypoxaemia also led to increased concentrations of fetal adrenal ACTH receptor mRNA, consistent with increased overall responsiveness of the fetal HPA axis. When fetuses at two-thirds of term gestation were subjected to hypoxaemia by repeated umbilical cord occlusion over several days, the adrenal cortisol response relative to the concentration of ACTH stimulation increased. Other experimental models of sustained, but episodic, fetal hypoxaemia produce similar fetal hormonal and cardiovascular responses, and may result in shortened gestation.

Increases in fetal HPA function in animal species such as sheep lead to changes in the placental output of progesterone before birth. During pregnancy, progesterone is required for uterine growth, but it simultaneously suppresses expression of CAP genes (Lye et al., 1998). At term, in most animal species, the influence of progesterone on the myometrium declines, uterine stretch no longer stimulates uterine growth and the increase in wall tension caused by continued fetal growth becomes translated into increased expression of CAP genes and myometrial activation. Mechanical stretch probably contributes to the greater incidence of preterm birth in pregnancies with multiple fetuses, and may account for the higher incidence of preterm birth in pregnancies in which the fetal size is large for gestational age. However, in human parturition there does not appear to be a decline in circulating progesterone concentrations prepartum. We suggest below that this represents a mechanism to maintain relaxation of the lower uterine segment at the time of birth, and that local antagonism of progesterone action in the fundal region of the uterus facilitates development of uterine contractions predominantly in the fundal region (Lye et al., 1998; Challis et al., 2000).

\section{Prostaglandins and parturition}

There is compelling evidence that PGs, particularly those produced within the intrauterine tissues, play a central role in the initiation and progression of labour in most mammalian species studied (Novy and Liggins, 1980; Okazaki et al., 1981; Bleasdale and Johnston, 1984; Mitchell, 1984; Challis and Lye, 1994; Challis et al., 2000). Specifically, PGs have been shown to induce myometrial contractility (Carraher et al., 1983; Wiqvist et al., 1983; Ritchie et al., 1984; Bennett et al., 1987a) and to play a role in regulating changes in extracellular matrix metabolism associated with cervical ripening (Ellwood et al., 1980; Ulmsten et al., 1982; Calder and Greer, 1991; Keirse, 1993) at the onset of labour. In addition, other roles have been postulated, including fetal adaptation to the labour process (PGs inhibit fetal movement and breathing to conserve energy) (Kitterman, 1987; Thorburn, 1992), upregulation of the fetal HPA axis (Challis et al., 2000), membrane rupture (So, 1993; Vadillo-Ortega et al., 1994), and maintenance of uterine and placental blood flow (Rankin, 1976; Sastry et al., 1997, 1999; Carter, 1998; Challis, 2001).

Studies in late pregnant sheep have helped clarify the endocrine pathways leading to altered PG output prepartum. In sheep, $\mathrm{PGE}_{2}$ concentrations increase progressively in the fetal circulation over the last 15-20 days of gestation, corresponding temporally to the prepartum increase in fetal plasma cortisol, and consistent with the suggestion of stimulatory effects of $\mathrm{PGE}_{2}$ on the fetal HPA axis, and of cortisol on placental prostaglandin synthase type 2 (PGHS-2) gene expression (Lye et al., 1998). PGF $_{2 \alpha}$ increases in the maternal circulation, but only as a late event in pregnancy, co-incident with the marked prepartum increase in maternal free oestradiol concentration. Thus, the possibility was raised that, in late gestation sheep, $\mathrm{PGE}_{2}$ and $\mathrm{PGF}_{2 \alpha}$ were derived from different tissues within the pregnant uterus, and that their output was regulated by different control mechanisms (Gyomorey et al., 2000). 
Previous studies had indicated that the prepartum increase of cortisol increased placental $\mathrm{P}^{450_{\mathrm{C} 17}}$ expression, which resulted in increased placental oestrogen synthesis from C21 steroids. In turn, oestrogen provoked increases in PG output (Challis et al., 2000). However, placental PGHS$2 \mathrm{mRNA}$ and protein were detectable, and increased before changes in placental $\mathrm{P} 40_{\mathrm{C} 17}$, and intrafetal oestradiol infusion had no stimulatory effect on placental PGHS-2. Conversely, intrafetal cortisol infusion for about $80 \mathrm{~h}$ resulted in increased placental PGHS-2 and fetal plasma $\mathrm{PGE}_{2}$ concentrations, even in the presence of an aromatase inhibitor. Therefore, this effect did not depend on the prepartum increase in placental oestrogen output (Whittle et al., 2000a). However, maternal uterine PGHS-2 expression and $\mathrm{PGF}_{2 \alpha}$ output were attenuated by concurrent aromatase inhibition during cortisol infusion. These studies indicated that upregulation of PGHS-2 in placental trophoblasts could be stimulated directly by cortisol. We have now substantiated this conclusion using cultures of ovine placental trophoblasts treated with glucocorticoids in vitro. Regulation of PGHS-2 in the maternal uterus required an increase in oestrogen output, even during cortisol infusion. This finding is consistent with observations in non-pregnant sheep that oestradiol treatment increases uterine PG output. In intact sheep at full term, the trophoblast cells express glucocorticoid receptor (GR) but not oestrogen receptor (ER). Similarly, immunoreactive GR and GR $\alpha$ are present in the trophoblast cells, and the abundance of GR $\alpha$ is increased by cortisol infusion, in the presence or absence of aromatase inhibition. Therefore, it appears that the prepartum increase in fetal plasma cortisol increases GR $\alpha$ activity in the placenta, and directly augments placental PG synthase. $\mathrm{P}_{450} \mathrm{C} 17_{7}$ concentrations were increased in animals treated with cortisol, and with cortisol plus aromatase inhibition. Therefore, $\mathrm{P}^{4} 50_{\mathrm{C} 17}$ increases independently of the prepartum increase in oestrogen. These results are consistent with the following sequence: cortisol upregulates placental PGHS-2 and the product $\mathrm{PGE}_{2}$ stimulates placental $\mathrm{P}_{450} \mathrm{C}_{17}$, as suggested for other tissues, including the adrenal glands. Definitive studies to demonstrate this relationship between $\mathrm{PGE}_{2}$ and $\mathrm{P}_{450} \mathrm{C}_{17}$ in the sheep placenta are still required.

\section{Prostaglandin synthesis and metabolism in human pregnancy}

In women, PG production and metabolism are discreetly compartmentalized within the tissues of the pregnant uterus (Challis et al., 2000). Human amnion, which consists of a single layer of epithelial cells and a subepithelial mesenchymal layer, is a major site of PG (predominantly $\mathrm{PGE}_{2}$ ) synthesis (Duchesne et al., 1978; Challis and Olson, 1988; Lundin-Schiller and Mitchell, 1990; Olson et al., 1991, 1995; Gibb and Sun, 1996). Both PGHS-1 and PGHS-2 mRNA and immunoreactive (IR) proteins have been identified in amnion (Rose et al., 1990; Teixeira et al., 1994; Hirst et al., 1995a). There is very low or no PG catabolizing enzyme, 15 hydroxyprostaglandin dehydrogenase (PGDH), present in human amnion (Keirse and Turnbull, 1975; Okazaki et al., 1981; Cheung et al., 1990). Interposed between amnion and decidua is the chorion, where a very high concentration of $\mathrm{PGDH}$ has been localized to the trophoblast cells (Keirse and Turnbull, 1975; Keirse et al., 1976, 1978, 1985; Okazaki et al., 1981; Cheung et al., 1990; van Meir et al., 1997a). PGHS is also abundant within chorion (Gibb and Sun, 1996). Thus, studies in vitro have demonstrated that chorion forms predominantly 13,14dihydro-15-keto products from endogenous precursors or from added PGE $_{2}$ (Skinner and Challis, 1985; Cheung and Challis, 1989). Human decidua, a well-vascularized maternal tissue lying next to the myometrium, consists of a mixture of decidualized stromal cells, bone marrow-derived macrophages and other types of cell, and contains low concentrations of both PGHS-1 and -2, and shows minimal PGDH staining in decidual stromal cells (Liggins et al., 1977; Okazaki et al., 1981; Casey and MacDonald, 1988; Cheung et al., 1990; MacDonald et al., 1991; Teixeira et al., 1994; Hirst et al., 1995b).

The fetus may contribute to the initiation of birth by secreting an active agent(s) that acts on the fetal membranes to stimulate PG production. PGHS activity and PGHS-2 mRNA concentrations are increased in amnion, in epithelial and fibroblast cells at term (Keirse and Turnbull, 1976; Mitchell et al., 1978; Okazaki et al., 1981; Bennett et al., 1992; Economopoulos et al., 1996; Gibb and Sun, 1996) and at preterm labour (Skinner and Challis, 1985; Teixeira et al., 1993; Hirst et al., 1995a; Slater et al., 1995). The predominant role that the amnion plays in PG output at term is exemplified by the increase in PG content of the amniotic fluid as labour progresses and the cervix dilates (Mitchell, 1988; Keirse, 1990). PGHS-2 expression and output of $\mathrm{PGE}_{2}$ increase at term and preterm labour within amnion epithelium and mesenchyme (Skinner and Challis, 1985; Lopez-Bernal et al., 1987a; Strickland and Mitchell, 1987; Teixeira et al., 1994; Hirst et al., 1995a; Fuentes et al., 1996; Gibb and Sun, 1996), although one early report failed to detect the increase in PGHS and PG output with labour in amnion (Satoh et al., 1981). PGHS-2 mRNA expression also increases in chorion with the onset of labour (Slater et al., 1995, 1998). Decidua may produce more PGF before labour than during labour (Harper et al., 1983), although most groups report that decidual PGHS-2 mRNA and protein do not change with labour (Harper et al., 1983; Casey and MacDonald, 1988; Fuentes et al., 1996; Gibb and Sun, 1996). In short, amnion, chorion and decidua produce increasing amounts of PGs throughout gestation but only amnion and chorion PG output and PGHS-2 mRNA increase further at the onset of labour (Olson et al., 1983; Skinner and Challis, 1985; Reddi et al., 1990; Teixeira et al., 1994; Freed et al., 1995; Hirst et al., 1995a; Slater et al., 1995; Fuentes et al., 1996).

Early studies indicated that PGDH protein and activity in the fetal membranes did not change significantly during spontaneous labour at full term (Skinner and Challis, 1985; 
Lopez-Bernal et al., 1987b; Casey et al., 1989; Cheung and Challis, 1989; Germain et al., 1994). However, current evidence indicates that mRNA expression and activity of chorionic PGDH decrease in human labour, at term and preterm (van Meir et al., 1996, 1997a,b; Sangha et al., 1994). PGDH mRNA concentrations in chorion obtained from patients at term during labour were lower than those obtained at term who were not in labour (Sangha et al., 1994). A role for altered expression of $\mathrm{PGDH}$ in preterm labour has also been suggested. Fifteen to twenty per cent of patients in idiopathic preterm labour, in the absence of intrauterine infection, had decreased IR-PGDH protein in chorion trophoblast cells, which was correlated with a decrease in PGDH activity in these patients (Sangha et al., 1994). In addition, there was low expression of IR-PGDH and $\mathrm{PGDH}$ mRNA in chorion collected from preterm deliveries associated with severe infection (van Meir et al., 1996, 1997a) in which there was loss of trophoblast cells. This finding indicates that, in some patients in preterm labour without infection, a deficiency in chorion $\mathrm{PGDH}$ allows passage of PGs, generated in amnion or chorion, across the membranes, which may be involved in the initiation of preterm labour. In all of these studies, changes in $\mathrm{PGDH}$ activity in chorion correlated with changes in concentrations of PGDH mRNA in the tissue.

There may be a regional distribution of PGDH activity in human fetal membranes. At labour, there is a marked reduction in PGDH activity in chorion collected from the region over the internal os of the cervix compared with tissue taken adjacent to the placental plate or from the middle region of the chorioamniotic sac (van Meir et al., 1996). This decrease in $\mathrm{PGDH}$ of cervical chorion at the time of labour is not associated with loss of trophoblast cells, indicating a potential role for altered expression of PGDH in the processes of cervical effacement and ripening. The active PGDH in decidua indicates that the PGs produced within this tissue are rapidly inactivated; however, uneven distribution of PGDH in decidua might allow areas of significant high local concentration.

As stated earlier, there are several possible roles for PGs derived from the fetal membranes. Amnion PGs may play a role in fluid or ion balance as they are potent mediators of transmembrane ion flow (Ramwell and Shaw, 1970; Frazier and Yorio, 1992; Saunders-Kirkwood et al., 1993). A role for amniotic PGs in cervical ripening, membrane rupture through effects on matrix metalloproteinases and myometrial contractility has also been postulated ( $\mathrm{Xu}$ et al., 2002). There are conflicting reports as to whether amnionderived PGs can transfer across fetal membranes and play a role in the initiation of labour. Several reports indicate that there is very limited transfer of unmetabolized PG from amnion to decidua before and after labour at term (McCoshen et al., 1987, 1990; Casey et al., 1989; Roseblade et al., 1990; Sullivan et al., 1991, 1992, 1993; Collins et al., 1992; Mitchell et al., 1993; Kredentser et al., 1995). In contrast, three studies using in vitro techniques have shown that small amounts of radioactive $\mathrm{PGE}_{2}$ can cross the membranes from the amniotic side to the decidual-myometrial side (Nakla et al., 1986; Bennett et al., 1990; Johnston et al., 1996) and Nakla et al. (1986) noted an increased rate of transfer or permeability of the membranes after spontaneous labour and demonstrated that arachidonic acid could also pass from amnion to decidua, potentially contributing to the substrate source for PGHS activity at that site. Similarly, Bennett et al. (1990) showed that lipoxygenase products (5-HETE) could pass across the membranes by diffusion through intercellular channels and remain largely unmetabolized.

Thus, the chorion, interposed between amnion and decidua, becomes an important PG metabolizing site and has been described as a protective barrier preventing the free transfer of primary PGs generated within amnion or chorion from passing unmetabolized to the underlying decidual tissue or myometrium (Nakla et al., 1986; Sullivan et al., 1992, 1993) and stimulating the onset of preterm or term delivery. Any reduction in the metabolizing capacity of the chorion may enhance PG transfer. In the presence of high PGDH activity in chorion during normal term labour, it is likely that PGs that are stimulating myometrial activity are derived from decidua or, locally, from the myometrium itself. However, in some circumstances of preterm labour, the $\mathrm{PGDH}$ metabolic barrier may break down, allowing PGs generated elsewhere within membranes to reach the underlying myometrium, and provoke premature delivery. Examination of the heterogeneous distribution of $\mathrm{PGDH}$ within the chorion (Cheung and Challis, 1989) indicates that protection of PG transfer across membranes by $\mathrm{PGDH}$ may not be uniform, allowing PGs produced in the amnion to pass through to the myometrium irrespective of changes in PGDH within the chorion (Challis et al., 1990; Cheung et al., 1990). Although several studies have examined PG transfer across the membranes at term and in the presence and absence of labour, studies to examine amnion- or chorion-derived PG transfer to the myometrium at preterm, when there are changes in PGDH activity and mRNA expression, and in correlation with concentrations of $\mathrm{PGDH}$ protein and PGDH activity at various sites within the uterus, have not been performed.

It is unclear whether there are changes in PGHS activity in human myometrium at the time of labour. In rats, both PGHS-1 and PGHS-2 were reported to increase with the onset of labour (Dong et al., 1996; Tsuboi et al., 2000), although other authors found increased mRNA expression of PGHS-2 but not PGHS-1 (Lye et al., 1998). In women, concentrations of PGHS in myometrium are higher during the pregnant than during the non-pregnant state (Moonen et al., 1984). PGHS-1 and PGHS-2 mRNA and protein have been reported to increase (Erkinheimo et al., 2000), decrease (Zuo et al., 1994) or remain unchanged (Myatt and Moore, 1994; Moore et al., 1999; Sparey et al., 1999) at the onset of labour at term and preterm. Ongoing studies have also failed to demonstrate changes in concentrations of PGHS-2 with labour at term in human myometrium collected from the lower uterine segment (Giannoulias et al., 2002), 


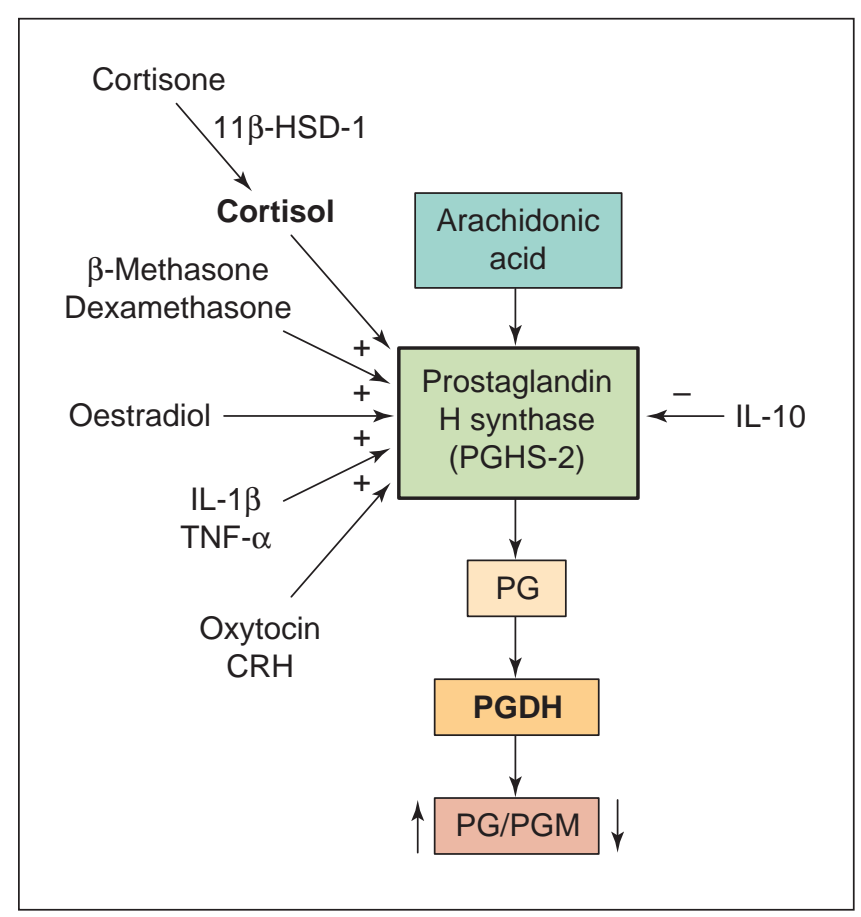

Fig. 2. Regulatory factors involved in the stimulation and inhibition of PGHS-2 (prostaglandin $\mathrm{H}$ synthase) in human intrauterine tissues. 11 -HSD: 11 -hydroxysteroid dehydrogenase; IL-1 $\beta$ : interleukin $1 \beta$; TNF- $\alpha$ : tumour necrosis factor $\alpha$; $\mathrm{CRH}$ : corticotrophin-releasing hormone; $\mathrm{PGDH}$ : $15-\mathrm{OH}$ prostaglandin dehydrogenase; PGM: prostaglandin metabolite. (Adapted from Challis et al., 2000.)

although PGDH protein was lower in samples collected from women at term and preterm in labour.

Excitatory (FP, EP3, EP1) PG receptors, as well as the relaxant EP2 receptor, have been localized to human nonpregnant myometrial samples (Senior et al., 1991, 1992). These receptor subtypes are also present in pregnant human myometrium in late pregnancy (Hofmann et al., 1983; Adelantado et al., 1988; Senior et al., 1993; Erkinheimo et al., 2000). There is no evidence for increased FP receptor density or increased coupling to phospholipase C (PLC) during pregnancy or parturition (Word et al., 1992).

\section{Regional controls of uterine contractility}

Several studies in humans and other species have shown that expression of the oxytocin receptor, $\mathrm{CRH}$ receptor type 1 (CRH-R1), and PG receptors within the uterus differ spatially (Fuchs et al., 1984; Moonen et al., 1986; Adelantado et al., 1988; Smith et al., 1996; Lye et al., 1998; Stevens et al., 1998). Thus, it has been suggested that during labour the myometrium exhibits a regionalization of function that allows for the effective and forceful net expulsion of the fetus from the uterus (Lye et al., 1998). The fundus increases expression of CAP genes in a manner similar to that in other species, whereas the lower segment expresses genes that contribute to relaxation (thus facilitating descent of the fetus during labour). In favour of this hypothesis, Wikland et al. (1984) demonstrated in vitro that $\mathrm{PGF}_{2 \alpha}$ stimulated the fundal myometrium during labour, but not before labour, whereas $\mathrm{PGE}_{2}$ was able to stimulate fundal myometrium both before and during labour. In lower segment myometrium, $\mathrm{PGF}_{2 \alpha}$ stimulated contractility before labour but had no effect during labour, whereas $\mathrm{PGE}_{2}$ induced a biphasic dose-dependent response (stimulation followed by inhibition) before labour but only inhibited contractility during labour (Wikland et al., 1984; Senior et al., 1993). Consistent with this finding, various groups have reported that EP2 expression in myometrium is higher preterm than at term (Molnar and Hertelendy, 1990). In rats, parturition is associated with downregulation of EP receptor subtypes and with upregulation of myometrial FP receptors, effecting a switch from inhibition to stimulation (Brodt-Eppley and Myatt, 1998, 1999; Dong and Yallampalli, 2000; Ou et al., 2000).

These studies raise the possibility that PGHS and PGDH may also be spatially regulated in the myometrium. Higher concentrations of PGHS-1 and PGHS-2 were found in lower compared with upper segments of the uterus (Moonen et al., 1986; Sparey et al., 1999). Labour-associated decreases in PGDH mRNA were found in the fundus compared with the lower uterine segment in the myometrium of baboons $(\mathrm{Wu}$ et al., 2000). However, the relative importance of autocrine control of myometrial contractility, versus paracrine control by PGs from amnion or chorion in relation to labour onset, remains unclear at present.

\section{Regulation of prostaglandin synthesis}

Regulation of PGHS-1 and PGHS-2 expression is multifactorial (Wang et al., 1993; Goppelt-Struebe, 1995, 1997; Schaefers and Goppelt-Struebe, 1996) (Fig. 2). PGHS-2 can be increased rapidly up to 80-fold in response to cytokines (Romero et al., 1989a,b,c, 1991), growth factors (EGF, PAF) (Mitchell, 1988; Romero et al., 1989a,b,c), tumour promoters (for example, phorbol esters), bacterial endotoxins (Bennett et al., 1987b; Lamont et al., 1990), oxytocin (Zeeman et al., 1997; Molnar et al., 1999; Soloff et al., 2000), agents that increase intracellular cAMP concentrations (Bleasdale and Johnston, 1984; Warrick et al., 1985; Anteby et al., 1997; Grammatopoulos and Hillhouse, 1999a), such as CRH (Jones and Challis, 1990a,b), and a variety of other factors, including, paradoxically in fetal membranes, glucocorticoids (Novy and Walsh, 1983; Mitchell et al., 1988; Potestio et al., 1988; Zakar and Olson, 1989; Gibb and Lavoie, 1990; Smieja et al., 1993; Blumenstein et al., 2000; Whittle et al., 2000a). The PGHS2 promoter region possesses several potential regulatory sequences including: TATA box, AP-2, SP1, nuclear factor $\kappa B(N F-\kappa B), C R E$, nuclear factor-interleukin 6 (NF-IL6), ETS1 and glucocorticoid response element (GRE) sites (Tazawa et al., 1994; Inoue et al., 1995). 
The ability of pro-inflammatory cytokines, particularly interleukin $1 \beta(\mathrm{IL}-1 \beta)$, to upregulate $\mathrm{PGI}_{2}$ and $\mathrm{PGE}_{2}$ synthesis in primary cultures of human myometrial cells has been well established (Hertelendy et al., 1993; Gomez et al., 1995). IL-1 $\beta$ rapidly induces PGHS-2 mRNA expression and $\mathrm{PGE}_{2}$ production in primary human amnion cells, chorion and decidua (Mitchell et al., 1993a,b, 1994; Tahara et al., 1995; Trautman et al., 1996) and in an amnionderived cell line (WISH cells) (Xue et al., 1995). Dexamethasone inhibited IL-1 $\beta$-induced PGHS-2 mRNA and protein expression, and activity (Xue et al., 1996). Goodwin et al. (1998) reported that IL-1 $\beta$ and tumour necrosis factor $\alpha(\mathrm{TNF}-\alpha)$, but not TGF- $\beta$, stimulate $\mathrm{PGE}_{2}$ production in cultured placental trophoblast cells. In contrast, Pomini et al. (1999) found that, although IL-1 $\beta$ stimulates PGHS-2 expression and $\mathrm{PGE}_{2}$ output by cultured villous and chorion trophoblast, TNF- $\alpha$ had no effect. These effects of IL-1 $\beta$ were reversed by co-incubation with the anti-inflammatory cytokine, IL-10, in placenta and chorion, although IL-10 alone produced a modest stimulation of $\mathrm{PGE}_{2}$ output and PGHS-2 mRNA concentrations in chorion explants. This finding is consistent with IL-10 stimulating rather than inhibiting PG production in amnion explants (Dudley et al., 1993; Mitchell et al., 1994). IL-1 $\beta$ appears to increase not only the rate of transcription of the PGHS-2 gene (Mitchell et al., 1993b, 1994), but also the stability of PGHS-2 mRNA (Ristimaki et al., 1994). p50 and p65, key members of the NF- $\mathrm{KB}$ Rel family of proteins, are present in trophoblast cells and probably serve as mediators of cytokine-induced upregulation of PGHS-2 expression (Kniss, 1999). It has been suggested that the stimulation of PG synthesis caused by cytokines is greater than the increase due to PGHS activity alone (Edwin et al., 1996), implying that cytokines have multiple sites of action, including effects on phospholipase, PG synthases and $\mathrm{PGDH}$, all of which contribute to the net stimulation of PG output. Indeed, IL-1 $\beta$ has been shown to induce CPLA2 mRNA expression in WISH cells (Xue et al., 1996). IL-1 $\beta$, IL-10 and TNF- $\alpha$ also downregulate PGDH activity and expression (see below). Thus, in vivo, it appears that the relative amounts of eicosanoids and cytokines produced from an interactive cytokine-eicosanoid cascade are critical in regulating the final response of the tissue and the amount of PG produced (Keelan et al., 1997). These results also raise the possibility that anti-inflammatory cytokines might be used therapeutically to modulate the action of compounds such as IL-1. Regulation of enzymes in the PG metabolic pathway by cytokines is likely in preterm patients with infection; however, regulation of these enzymes in term patients and in preterm patients without infection may be related to a different set of regulators.

Normally, PGHS-2 is induced under conditions of inflammation. Glucocorticoids inhibit PGHS-2 transcription and reduce PGHS-2 mRNA stability (DeWitt and Meade, 1993; Evett et al., 1993), representing one pathway of anti-inflammatory action. However, several studies have shown that PG production in cultured amnion and chorion is stimulated by cortisol and the synthetic glucocorticoid dexamethasone (Novy and Walsh, 1983; Mitchell et al., 1988; Potestio et al., 1988; Zakar and Olson, 1989; Gibb and Lavoie, 1990; Smieja et al., 1993; Economopoulos et al., 1996; Patel et al., 1999; Blumenstein et al., 2000; Whittle et al., 2000b). The amnion consists of a single layer of epithelial cells and a subepithelial mesenchymal layer. At term, the basal output of PG by amnion mesenchymal cells exceeds that of amnion epithelial cells (Whittle et al., 2000a). Glucocorticoids may have dual effects in different types of cell within amnion. Glucocorticoids appear to inhibit $\mathrm{PGE}_{2}$ output in amnion epithelial cells (Blumenstein et al., 2000), whereas in mesenchymal fibroblast cells, they upregulate PGHS-2 mRNA expression and increase $\mathrm{PGE}_{2}$ output (Potestio et al., 1988; Economopoulos et al., 1996). However, Whittle et al. (2000a) reported that glucocorticoids stimulate PG production in amnion epithelial cells but that there was no significant change in the already increased output of PG from mesenchymal fibroblast cells. Glucocortocoid receptors have been localized to amnion epithelium, amnion mesenchymal fibroblasts, chorion trophoblast cells, and placenta in human pregnancy tissues at term and preterm (Giannopoulos et al., 1983; Karalis et al., 1996; Sun et al., 1996; Weisbart and Huntley, 1997). In mixed amnion cell cultures, the action of glucocorticoids is dependent upon interaction with GR and apparently requires activation of protein kinase C (PKC). Furthermore, the glucocorticoid regulation of $\mathrm{PG}$ output in amnion cells can be inhibited by addition of a GR antagonist (Alvi et al., 1999), and this finding is in agreement with a role for receptor mediation.

\section{Prostaglandin metabolism}

Biologically active concentrations of PG appear to depend not only on rates of synthesis, but also on the rates of metabolism (Challis et al., 1999). Normally, high concentrations of PGDH expressed in chorion trophoblasts would be expected to metabolize effectively PG generated within amnion or chorion. However, patients in preterm labour with an underlying infective process have markedly reduced numbers of trophoblasts in the chorion layer and markedly reduced PGDH activity (Sangha et al., 1994). In addition, approximately $15 \%$ of patients with idiopathic preterm labour have diminished expression of $\mathrm{PGDH}$ but normal numbers of trophoblasts. PGDH activity is reduced modestly in chorion from patients at term, but is markedly diminished in myometrium and cervix of patients presenting in preterm labour. Thus, reduced PG metabolism appears to be an effective way of increasing PGs that may then reach agonist $\mathrm{PG}$ receptors in a paracrine fashion. Furthermore, concentrations of matrix metalloproteinase 9 (MMP-9) in chorion are increased with term and preterm labour. Since this gelatinase enzyme contributes to the controlled degradation of collagen within the fetal membranes, and MMP-9 activity is increased by $\mathrm{PGE}_{2}$, this feedforward cascade may help explain the mechanism of 


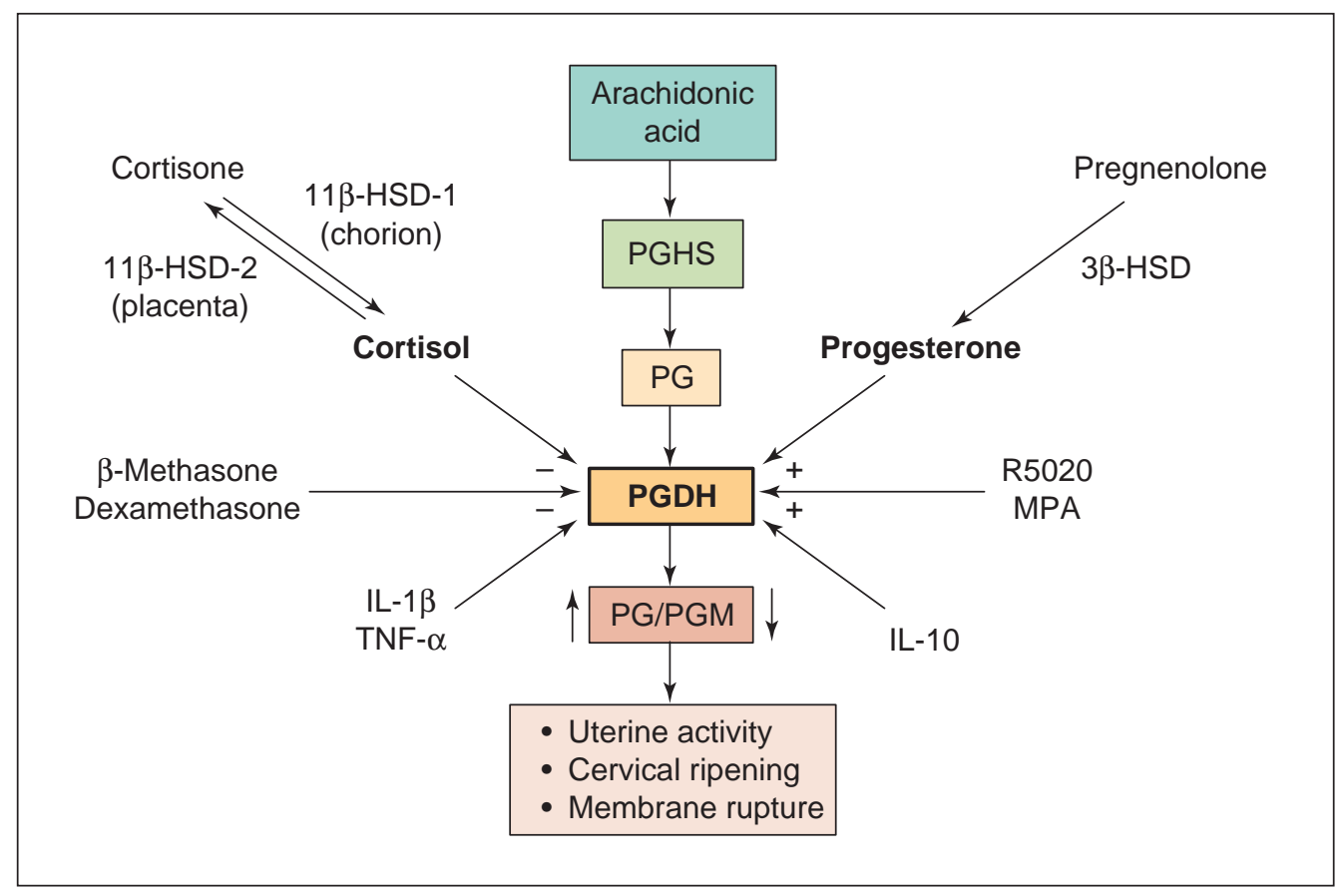

Fig. 3. Schematic representation factors that regulate $15-\mathrm{OH}$ prostaglandin dehydrogenase (PGDH) activity and expression in human fetal membranes and placenta. Progestins (produced intracellularly from pregnenolone conversion to progesterone by $3 \beta$-hydroxysteroid dehydrogenase $(3 \beta-\mathrm{HSD})$ or from the maternal circulation) stimulate PGDH acting to maintain prostaglandin concentrations throughout pregnancy. Glucocorticoids, either from the maternal circulation or produced locally via $11 \beta-H S D$ activity, inhibit PGDH activity and expression. Pro-inflammatory cytokines such as interleukin $1 \beta$ (IL-1 $\beta$ ) and tumour necrosis factor $\alpha$ (TNF- $\alpha$ ) inhibit PGDH, whereas anti-inflammatory cytokines such as IL-10 stimulate PGDH activity and expression. A downregulation of PGDH would lead to a higher prostaglandin (PG) to prostaglandin metabolite (PGM) ratio at term, which may result in increased uterine activity, cervical ripening or rupture of the fetal membranes. MPA: medroxyprogesterone acetate; PGHS: prostaglandin $\mathrm{H}$ synthase.

preterm premature rupture of the membranes, with MMP-9 providing the predominant gelatinolytic activity.

Many factors, including drugs (Flower, 1974), proteinmodifying agents, zinc and copper metal ions (Sakuma et al., 1990, 1996), hyperoxia (Parkes and Eling, 1975; Chaudhari et al., 1979; Vader et al., 1981; Pisarello et al., 1997), fatty acids, cAMP (Lennon et al., 1999), calcium, bacterial endotoxins (lipopolysaccharide) (Alam et al., 1973; Nakano and Prancan, 1973; Blackwell et al., 1976; Harper et al., 1980; Hahn et al., 1998), 1,25-dihydroxyvitamin D3 (Pichaud et al., 1997), vitamin E (Chan et al., 1980), thyroid hormones (Tai et al., 1974; Moore and Hoult, 1978), cytokines (Brown et al., 1998) and steroid hormones, have been implicated in the regulation of PGDH activity in a variety of species and types of cell (Nakano and Prancan, 1973; Andersen and Ramwell, 1974; Lee and Levine, 1975; Hansen, 1976; Tai and Hollander, 1976; Pace-Asciak and Smith, 1983; Krook et al., 1992; Okita and Okita, 1996). The $1.6 \mathrm{~kb}$ promoter region of the PGDH gene contains two TATA boxes and a number of potential regulatory elements, including Sp1, CRE, GRE, AP1, AP2,
NF-IL6, C-MYC and a putative oestrogen receptor binding site (Matsuo et al., 1996, 1997).

The presence of an NF-IL6 regulatory element in the promoter region of the $\mathrm{PGDH}$ gene indicates that $\mathrm{PGDH}$ may be regulated by cytokines (Matsuo et al., 1997) (Fig. 3). Indeed, cytokines such as IL-1 $\beta$ and, to a lesser extent, TNF- $\alpha$, have been reported to decrease PGDH mRNA and PGDH activity in intact fetal membrane disks and in cultured chorion and placental trophoblast cells (Brown et al., 1998; Pomini et al., 1999; Mitchell et al., 2000). In accordance with their effect on PGHS expression, anti-inflammatory cytokines such as IL-10 reverse IL-1 $\beta$ and TNF- $\alpha$ inhibition of PGDH.

Studies directed towards understanding the mechanism by which steroid hormones might regulate PGDH (Patel et al., 1999) (Fig. 3) have also revealed a mechanism for local progesterone withdrawal within the human fetal membranes. Human chorionic PGDH gene expression and activity are inhibited by glucocorticoids (cortisol, betamethasone and dexamethasone) and maintained in a tonic fashion by progesterone (Patel et al., 1999). Chorion trophoblasts express $3 \beta$-hydroxysteroid dehydrogenase ( $3 \beta$-HSD) 
and have the capacity to produce their own progesterone from pregnenolone (Bloch, 1945; Gibb et al., 1978; Challis and Vaughan, 1987; Mitchell and Challis, 1988; Riley et al., 1992). Inhibition of endogenous $3 \beta-H S D$ activity with the drug trilostane inhibited progesterone output from chorion trophoblast cells, and reduced PGDH mRNA. Replacement of progesterone or a synthetic progestagen restored PGDH activity. This effect could be blocked, in part, by a progesterone receptor antagonist. However, the action of progesterone to restore PGDH could also be blocked by a specific GR antagonist. This observation implies that progesterone, produced locally within chorion, acts throughout pregnancy to maintain chorionic PGDH activity through interacting with GR. At term, increased availability of endogenous cortisol would displace progesterone from GR, resulting in loss of the stimulation to PGDH, and also a direct inhibitory effect on PGDH expression. This interaction, whereby the effects of progesterone are mediated through GR but can be opposed by increased output of glucocorticoid, may provide a mechanism for producing local progesterone withdrawal in the human uterus. This activity may be greater in the fundal area, thereby contributing to regionalized changes in uterine contractions (Sparey et al., 1999; Challis et al., 2000).

The biologically inactive corticosteroid, cortisone, was almost as effective as cortisol in inhibiting PGDH in chorion cells, but not in placental trophoblast cells (Challis et al., 1999). In chorion, the action of cortisone could be blocked by a GR antagonist, and was completely attenuated in the presence of the drug carbonexolone. This drug, an active ingredient of liquorice, inhibits the enzyme 11ßhydroxysteroid dehydrogenase 1 (11 $\beta$-HSD-1). 11 $\beta$-HSD-1 is abundantly expressed in chorion trophoblasts, and predominantly converts cortisone to cortisol. Thus, chorion trophoblasts have the potential to form cortisol locally from cortisone, in addition to forming progesterone locally from pregnenolone. In theory, therapeutic regulation of $\mathrm{PGDH}$ could be accomplished by steroid hormones, or by drugs that alter the concentration of $11 \beta-H S D-1$.

\section{$\mathrm{CRH}$ and preterm labour}

It is now well established that the concentrations of $\mathrm{CRH}$ in maternal blood increase progressively during human pregnancy (Linton et al., 1993; Petraglia et al., 1996). This increase correlates with increased $\mathrm{CRH}$ mRNA and $\mathrm{CRH}$ peptide in placental tissue (Frim et al., 1988). In the circulation, $\mathrm{CRH}$ is largely associated with a high-affinity circulating $\mathrm{CRH}$-binding protein $(\mathrm{CRH}-\mathrm{BP})$ produced in the liver, placenta and other sites including the brain. $\mathrm{CRH}-\mathrm{BP}$ effectively blocks the action of placental $\mathrm{CRH}$ on the maternal pituitary and on the myometrium. Near term, and in association with preterm labour, $\mathrm{CRH}-\mathrm{BP}$ concentrations decrease, coincident with the increase in circulating $\mathrm{CRH}$ (Linton et al., 1993). Thus, it has been suggested that the substantial increase in free $\mathrm{CRH}$ concentrations in systemic plasma is a component of the trigger to the labour process.
Regulation of placental CRH output is multifactorial, and has been reviewed extensively (Petraglia et al., 1996). Paradoxically, $\mathrm{CRH}$ gene expression and $\mathrm{CRH}$ output by placental trophoblast cells are increased by glucocorticoids. CRH output from placenta and fetal membranes also increases in response to PGs, cytokines and catecholamines, and is decreased by nitric oxide and progesterone. Karalis et al. (1996) suggested that the inhibitory effect of progesterone is exerted through binding to GR in trophoblast cells. At term, increased cortisol may displace progesterone bound to GR and this is reflected as an increase in $\mathrm{CRH}$ output. Thus, the mechanism of interaction between progesterone and cortisol in the regulation of $\mathrm{CRH}$ is similar to that proposed for the regulation of $\mathrm{PGDH}$.

The action of $\mathrm{CRH}$ on the intrauterine tissues and myometrium is effected through an extensive network of high affinity $\mathrm{CRH}$ receptors with different specificities. There are two main classes of $\mathrm{CRH}$ receptor, $\mathrm{CRH}-\mathrm{R} 1$ and $\mathrm{CRH}-\mathrm{R} 2$. In myometrium, $\mathrm{CRH}$ acts by binding to $\mathrm{CRH}-\mathrm{R} 1$, which is coupled to $\mathrm{G}_{\alpha} \mathrm{s}$, leading to stimulation of cAMP output. Thus, the primary effect of $\mathrm{CRH}$ throughout pregnancy is likely to be one of uterine relaxation. The binding affinity of the $\mathrm{CRH}$ receptor in human myometrium increases during pregnancy, but then decreases before parturition. Grammatopoulos et al. (1999b,c) suggested that oxytocin effects this change by upregulating a PKC that phosphorylates the $\mathrm{CRH}$ receptor protein, resulting in desensitization and loss of the inhibitory influence of $\mathrm{CRH}$ on myometrium. Therefore, the peptide $\mathrm{CRH}$ may act as an inhibitor or stimulant to the myometrium, depending upon the affinity and second messenger of the different receptor species (Spaziani et al., 2000; Karteris et al., 2001).

The differential effects of $\mathrm{CRH}$ on the myometrium may also contribute to the regionalization of myometrial activity at term and in the preterm period. Stevens et al. (1998) showed that the expression of CRH-R1 in myometrium collected from the lower uterine segment was higher in patients in labour compared with those not in labour. Furthermore, expression of CRH-R1 was substantially higher in lower segment compared with fundal myometrium when paired samples of tissue from individual patients were examined. Thus, during labour, $\mathrm{CRH}$ may promote relaxation of the lower segment but stimulate activity in the body of the uterus. This stimulatory action could be direct or indirect, as $\mathrm{CRH}$ stimulates output of PGs by upregulating PGHS-2 and downregulating $\mathrm{PGDH}$ in human fetal membranes.

It is possible that increasing maternal plasma CRH concentration may be used to predict women destined to enter preterm labour. McLean et al. (1995) demonstrated increased maternal plasma concentrations of $\mathrm{CRH}$ as early as weeks 14-16 of pregnancy in women who subsequently delivered preterm, and lower concentrations of $\mathrm{CRH}$ in the plasma of women who delivered post term. Korebrits et al. (1998) found that maternal plasma CRH concentrations were higher in patients at weeks 28-32 of pregnancy with an initial diagnosis of threatened preterm labour, who 


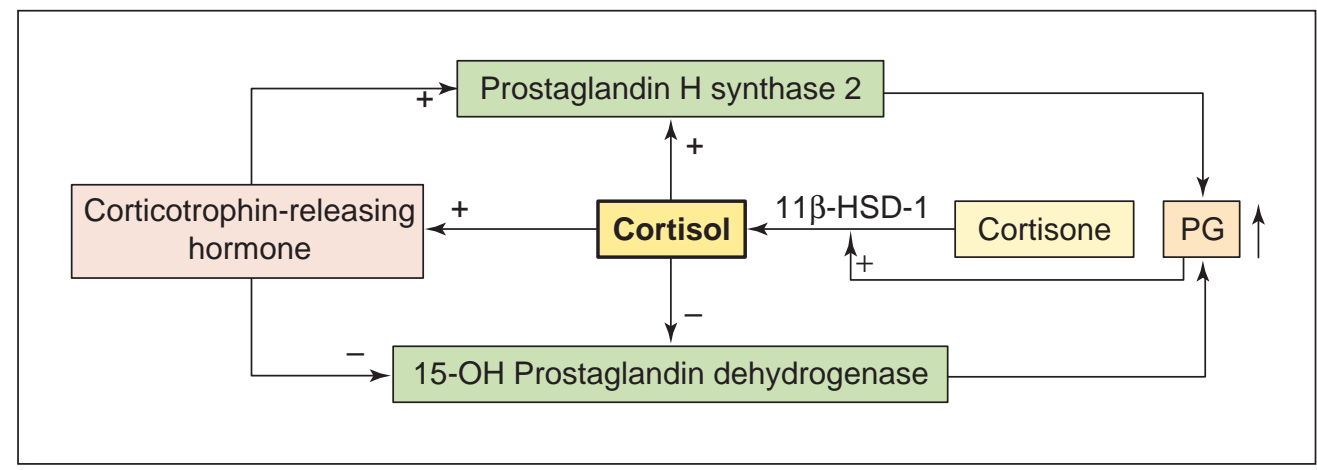

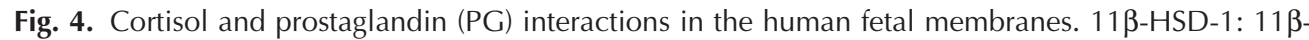
hydroxysteroid dehydrogenase 1. (Adapted from Challis et al., 2000.)

delivered within $48 \mathrm{~h}$. However, $\mathrm{CRH}$ concentrations were within the normal range in patients with the same initial diagnosis who proceeded to delivery at term. At present, it seems unlikely that a single measurement of maternal plasma $\mathrm{CRH}$ will provide an adequate means of predicting the patient who is at risk of preterm labour. However, a combination of biochemical tests including $\mathrm{CRH}$ and salivary oestriol, combined with measurements of fibronectin, may be of sufficient sensitivity and specificity to be used clinically.

\section{Birth - an integrated series of autocrine-paracrine loops?}

From the preceding discussion, it should be apparent that birth, at term and preterm, results from processes leading to increased PG output. Glucocorticoids have a central role in those processes, stimulating $\mathrm{CRH}$ output within placenta and fetal membranes. Similarly, $\mathrm{CRH}$ upregulates PGHS-2 and downregulates $\mathrm{PGDH}$. The effects of $\mathrm{CRH}$ may be modulated by the state of the $\mathrm{CRH}$ receptor. Oxytocin appears to play a key role in changing the affinity of $\mathrm{CRH}$ receptor interaction. Oxytocin may be derived from the systemic circulation, and also locally from chorion or decidua.

Increased concentrations of cortisol may be derived from the maternal circulation, for example in association with a maternal stress response, or from the fetus after precocious activation of the fetal HPA axis. In addition, cortisol can be formed locally within chorion trophoblast cells from the inactive precursor cortisone. The expression of $11 \beta-H S D-1$, which effects this conversion, increases in chorion trophoblasts progressively during human gestation. Alfaidy and Challis (2000) have demonstrated that $\mathrm{PGE}_{2}$ and $\mathrm{PGF}_{2 \alpha}$ act to increase local cortisol concentrations in chorion (Fig. 4). $\mathrm{PGE}_{2}$ and $\mathrm{PGF}_{2 \alpha}$ increase $11 \beta-\mathrm{HSD}-1$ activity in chorion via a $\mathrm{Ca}^{2+}$-dependent mechanism, which also results in increased production of cortisol derived either from circu- lating cortisone or from increased cortisone in the amniotic fluid owing to a developing fetal HPA axis. Furthermore, $\mathrm{PGE}_{2}$ and $\mathrm{PGF}_{2 \alpha}$ decrease $11 \beta-\mathrm{HSD}-2$ activity in placenta, which also results in an increase in local cortisol concentrations. This cortisol can then act on PGDH, PGHS, and $\mathrm{CRH}$ to further increase PG concentrations. These feedforward loops serve to increase both local cortisol and local PG concentrations. The increase in intracellular cortisol at term may facilitate withdrawal of progesterone effects at the GR as a result of increased cortisol concentrations and a higher affinity of cortisol for its own receptor. Where there is infection, other agents such as cytokines can intercede in this series of autocrine-paracrine loops by stimulating PGHS-2 and downregulating PGDH expression. In the presence of such complex intracellular feed-forward loops, it is not surprising that the prevention of preterm labour has eluded us. Current tocolytic therapies have been designed to block one part of this complex pathway by treating a symptom of labour such as uterine contractility rather than the underlying cause, and clearly this approach has been unsuccessful.

It is also apparent that the mechanisms that predispose to preterm labour almost certainly vary at different stages of gestation. The incidence of preterm birth in association with chorioamnionitis is higher earlier in pregnancy. Later in gestation, the fetal stress response may predominate. In this situation, fetal HPA activation increases fetal cortisol output which, in turn, upregulates placental $\mathrm{CRH}$ expression. This contention is consistent with the higher concentrations of $\mathrm{CRH}$ in the umbilical cord plasma of fetuses with intrauterine growth restriction (IUGR). Placental $\mathrm{CRH}$ also drives fetal adrenal steroidogenesis, leading to increased production of dehydroepiandrosterone (DHEA) from the fetal zone of the fetal adrenal. DHEA, in turn, is aromatized in the placenta to oestrogen, thereby contributing to myometrial activation.

An additional concern is the excessive use of synthetic glucocorticoids to promote fetal lung maturation in women 
who are at threat of preterm labour (Ballard and Ballard, 1995). Although there are many beneficial effects of endogenous glucocorticoids, such as maturation of fetal organ systems required for extrauterine life (Liggins, 1977; Ballard and Ballard, 1995), exogenous corticosteroids given to pregnant women at risk of preterm labour (Elliott and Radin, 1995; Yeshaya et al., 1996) and to animals (Liggins, 1968; Liggins et al., 1973), have been shown to increase uterine activity. The effects of exogenous corticosteroids on labour and delivery problems and neonatal outcomes in asthmatic women have been well researched. Perlow et al. (1992) showed that preterm delivery and premature rupture of membranes are more common among asthmatic women with data demonstrating a preterm delivery incidence of $54.8 \%$ for corticosteroid-dependent women and $14 \%$ for non-corticosteroid-dependent women. Other groups have also found that corticosteroid-dependent asthmatic women have significantly higher risks of premature rupture of membranes, preterm labour and delivery, Caesarean delivery and other maternal complications (Perlow et al., 1992; Doucette and Bracken, 1993; Demissie et al., 1998). Furthermore, corticosteroid-dependent women had a significantly higher incidence of low birth weight babies (Schatz et al., 1990; Perlow et al., 1992; Jana et al., 1995; Demissie et al., 1998).

Since the diagnosis of preterm labour cannot be made with accuracy because of a lack of any clear quantifiable marker, some patients may receive repeated corticosteroids unnecessarily (Ballard and Ballard, 1995). Risks of steroid exposure include adrenal insufficiency, growth retardation and immune suppression (Reinisch et al., 1978; Uno et al., 1990; Seckl and Meaney, 1993; Bakker et al., 1995; Barbazanges et al., 1996; Ikegami et al., 1997; Seckl and Miller, 1997) and the risks of repeated steroid exposure are unknown. Exposure to corticosteroids in utero may program the fetus for altered stress responses after birth that may predispose to adult onset diseases such as diabetes mellitus, hypertension and coronary heart disease (Seckl and Miller, 1997; Dodic et al., 1998). An additional risk of exogenous corticosteroids may be to precipitate preterm labour. Therefore, it is crucial that care is taken in the dose and repetition of corticosteroids given to women who appear to be threatened with preterm labour. The ability to predict or diagnose the patient in preterm labour will be invaluable in selecting those women for whom prenatal corticosteroids should be administered.

Work in the authors' laboratories has been supported by the Canadian Institute of Health Research (CIHR) Group in Fetal and Neonatal Health and Development. The authors gratefully acknowledge support from the Parke-Davies Fellowship Trust of the University of Cambridge.

\section{References}

Key references are identified by asterisks

Adelantado JM, Lopez-Bernal A and Turnbull AC (1988) Topographical distribution of prostaglandin E receptors in human myometrium British Journal of Obstetrics and Gynaecology 95 348-353
Alam NA, Clary P and Russell PT (1973) Depressed placental prostaglandin $\mathrm{E}_{1}$ metabolism in toxemia of pregnancy Prostaglandins 4 363-370

Alfaidy N and Challis JRG (2000) Prostaglandin effects on $11 \beta$ hydroxysteroid dehydrogenase type 1 and type 2 in human chorion and placental trophoblast cells. In Proceedings of the 47th Annual Meeting of the Society for Gynecologic Investigation Chicago, IL. Abstract 405

Alvi SA, Brown NL, Bennett PR, Elder MG and Sullivan MH (1999) Corticotrophin-releasing hormone and platelet-activating factor induce transcription of the type- 2 cyclo-oxygenase gene in human fetal membranes Molecular Human Reproduction 5 476-480

Andersen NH and Ramwell PW (1974) Biological aspects of prostaglandins Archives of Internal Medicine 133 30-50

Anteby EY, Johnson RD, Huang X, Nelson DM and Sadovsky Y (1997) Transcriptional regulation of prostaglandin- $\mathrm{H}$ synthase-2 gene in human trophoblasts Journal of Clinical Endocrinology and Metabolism 82 2289-2293

Bakker JM, Schmidt ED, Kroes H, Kavelaars A, Heijnen CJ, Tilders FJ and van Rees EP (1995) Effects of short-term dexamethasone treatment during pregnancy on the development of the immune system and the hypothalamo-pituitary adrenal axis in the rat Journal of Neuroimmunology 63 183-191

Ballard PL and Ballard RA (1995) Scientific basis and therapeutic regimens for use of antenatal glucocorticoids American Journal of Obstetrics and Gynecology 173 254-262

Barbazanges A, Piazza PV, Le Moal M and Macarri S (1996) Maternal glucocorticoid secretion mediates long-term effects of prenatal stress Journal of Neuroscience 16 3943-3949

Bennett PR, Elder MG and Myatt L (1987a) The effects of lipoxygenase metabolites of arachidonic acid on human myometrial contractility Prostaglandins 33 837-844

Bennett PR, Rose MP, Myatt L and Elder MG (1987b) Preterm labor stimulation of arachidonic acid metabolism in human amnion cells by bacterial products American Journal of Obstetrics and Gynecology 156 649-655

Bennett PR, Chamberlain GV, Patel L, Elder MG and Myatt L (1990) Mechanisms of parturition: the transfer of prostaglandin $E_{2}$ and 5hydroxyeicosatetraenoic acid across fetal membranes American Journal of Obstetrics and Gynecology 162 683-687

Bennett PR, Henderson DJ and Moore GE (1992) Changes in expression of the cyclooxygenase gene in human fetal membranes and placenta with labor American Journal of Obstetrics and Gynecology 167 212-216

Blackwell GJ, Flower RJ and Herman AG (1976) Effect of endotoxin on 15hydroxyprostaglandin dehydrogenase in the rabbit jejunum and lung Archives Internationales de Pharmacodynamie et de Therapie 220 325-326

Bleasdale JE and Johnston JM (1984) Prostaglandins and human parturition regulation of arachidonic acid mobilization Reviews in Perinatology and Medicine 5151

Bloch K (1945) The biological conversion of cholesterol to pregnanediol Journal of Biological Chemistry 157 661-666

Blumenstein M, Hansen WR, Deval D and Mitchell MD (2000) Differential regulation in human amnion epithelial and fibroblast cells of prostaglandin $\mathrm{E}_{2}$ production and prostaglandin $\mathrm{H}$ synthase-2 mRNA expression by dexamethasone but not tumour necrosis factor- $\alpha$ Placenta $21210-217$

Brodt-Eppley J and Myatt L (1998) Changes in expression of contractile FP and relaxatory $\mathrm{EP}_{2}$ receptors in pregnant rat myometrium during late gestation, at labor, and postpartum Biology of Reproduction 59 878-883

Brodt-Eppley J and Myatt L (1999) Prostaglandin receptors in lower segment myometrium during gestation and labor Obstetrics and Gynecology 93 89-93

Brown NL, Alvi SA, Elder MG, Bennett PR and Sullivan MH (1998) Interleukin-1 $\beta$ and bacterial endotoxin change the metabolism of prostaglandins $\mathrm{E}_{2}$ and $\mathrm{F}_{2 \alpha}$ in intact term fetal membranes Placenta 19 625-630

Calder AA and Greer IA (1991) Pharmacological modulation of cervical compliance in the first and second trimesters of pregnancy Seminars in Perinatology 15 162-172 
Carraher R, Hahn DW, Ritchie DM and McGuire JL (1983) Involvement of lipoxygenase products in myometrial contractions Prostaglandins $\mathbf{2 6}$ 23-32

Carter AM (1998) Few autacoids have a proven role in the physiological regulation of fetal placental blood flow Trophoblast Research 11 279-297

Casey ML and MacDonald PC (1988) Biomolecular processes in the initiation of parturition decidual activation Clinical Obstetrics and Gynecology 31 533-552

Casey ML, Delgadillo M, Cox KA, Niesert S and MacDonald PC (1989) Inactivation of prostaglandins in human decidua vera (parietalis) tissue: substrate specificity of prostaglandin dehydrogenase American Journal of Obstetrics and Gynecology $1603-7$

Challis JRG (2001) Endocrinology of parturition. In Endocrinology 4th Edn pp 2427-2432 Eds LJ DeGroot and JL Jameson. WB Saunders Co., Philadelphia

Challis JRG and Lye SJ (1994) Parturition. In The Physiology of Reproduction Vol. 2 pp 985-1031 Eds E Knobil and JD Neill. Raven Press, New York

Challis JRG and Olson DM (1988) Parturition. In The Physiology of Reproduction pp 2177-2216 Eds E Knobil and JD Neill. Raven Press, New York

Challis JRG and Vaughan M (1987) Steroid synthetic and prostaglandin metabolizing activity is present in different cell populations from human fetal membranes and decidua American Journal of Obstetrics and Gynecology 157 1474-1481

Challis JRG, Jacobs RA, Riley SC, Boshier DP, Han VK, Smith W, Cheung PYC, Langlois D and Fraher L (1990) Distribution of prostaglandin synthesizing and metabolizing enzymes in intrauterine tissues. In Uterine Contractility Mechanisms of Control pp 143-152. Ed. RE Garfield. Serono Symposium, Norwell, MA

Challis JRG, Patel FA and Pomini F (1999) Prostaglandin dehydrogenase and the initiation of labor Journal of Perinatal Medicine 27 26-34

*Challis JRG, Matthews SG, Gibb W and Lye SJ (2000) Endocrine and paracrine regulation of birth at term and preterm Endocrine Reviews 21 514-550

Chan AC, Hegarty PV and Allen CE (1980) The effects of vitamin E depletion and repletion on prostaglandin dehydrogenase activity in tissues of young rabbits Journal of Nutrition $11074-81$

Chaudhari A, Sivarajah K, Warnock R, Eling TE and Anderson MW (1979) Inhibition of pulmonary prostaglandin metabolism by exposure of animals to oxygen or nitrogen dioxide Biochemical Journal 184 51-57

Cheung PYC and Challis JRG (1989) Prostaglandin $E_{2}$ metabolism in the human fetal membranes American Journal of Obstetrics and Gynecology 161 1580-1585

Cheung PYC, Walton JC, Tai HH, Riley SC and Challis JRG (1990) Immunocytochemical distribution and localization of 15-hydroxyprostaglandin dehydrogenase in human fetal membranes, decidua, and placenta American Journal of Obstetrics and Gynecology 163 1445-1449

Collins PL, Goldfien A and Roberts JM (1992) Exposure of human amnion to amniotic fluid obtained before labor causes a decrease in chorion/ decidual prostaglandin release Journal of Clinical Endocrinology and Metabolism 74 1198-1205

Copper RL, Goldenberg RL, Creasy RK, DuBard MB, Davis RO, Entman SS, lams JD and Cliver SP (1993) A multicenter study of preterm birth weight and gestational age-specific neonatal mortality American Journal of Obstetrics and Gynecology 168 78-84

Creasy RK (1991) Preventing preterm birth New England Journal of Medicine 325 727-729

Creasy RK and Gummer BA (1980) System for predicting spontaneous preterm birth Obstetrics and Gynecology 55 692-695

Demissie K, Breckenridge MB and Rhoads GG (1998) Infant and maternal outcomes in the pregnancies of asthmatic women American Journal of Respiratory and Critical Care Medicine 158 1091-1095

DeWitt DL and Meade EA (1993) Serum and glucocorticoid regulation of gene transcription and expression of the prostaglandin $\mathrm{H}$ synthase- 1 and prostaglandin $\mathrm{H}$ synthase-2 isozymes Archives of Biochemistry and Biophysics 306 94-102

Dodic M, May CN, Wintour EM and Coghlan JP (1998) An early prenatal exposure to excess glucocorticoid leads to hypertensive offspring in sheep Clinical Science 94 149-155

Dong YL and Yallampalli C (2000) Pregnancy and exogenous steroid treatments modulate the expression of relaxant EP2 and contractile FP receptors in the rat uterus Biology of Reproduction 62 533-539

Dong YL, Gangula PR, Fang L and Yallampalli C (1996) Differential expression of cyclooxygenase- 1 and -2 proteins in rat uterus and cervix during the estrous cycle, pregnancy, labor and in myometrial cells Prostaglandins 52 13-34

Doucette JT and Bracken MB (1993) Possible role of asthma in the risk of preterm labor and delivery Epidemiology 4 143-150

Duchesne MJ, Thaler-Dao H and de Paulet AC (1978) Prostaglandin synthesis in human placenta and fetal membranes Prostaglandins 15 19-42

Dudley DJ, Trautman MS and Mitchell MD (1993) Inflammatory mediators regulate interleukin-8 production by cultured gestational tissues: evidence for a cytokine network at the chorio-decidual interface Journal of Clinical Endocrinology and Metabolism 76 404-410

Economopoulos P, Sun M, Purgina B and Gibb W (1996) Glucocorticoids stimulate prostaglandin $\mathrm{H}$ synthase type-2 (PGHS-2) in the fibroblast cells in human amnion cultures Molecular and Cellular Endocrinology 117 141-147

Edwin SS, Trautman MS and Mitchell MD (1996) Regulation of prostaglandin $\mathrm{H}$ synthase-2 in chorion and decidual cells Prostaglandins, Leukotrienes and Essential Fatty Acids 55 211-216

Elliott JP and Radin TG (1995) The effect of corticosteroid administration on uterine activity and preterm labor in high-order multiple gestations Obstetrics and Gynecology 85 250-254

Ellwood DA, Mitchell MD, Anderson ABM and Turnbull AC (1980) The in vitro production of prostanoids by the human cervix during pregnancy: preliminary observations British Journal of Obstetrics and Gynaecology $87210-214$

Erkinheimo TL, Saukkonen K, Narko K, Jalkanen J, Ylikorkala $\mathbf{O}$ and Ristimaki A (2000) Expression of cyclooxygenase-2 and prostanoid receptors by human myometrium Journal of Clinical Endocrinology and Metabolism 85 3468-3475

Evett GE, Xie W, Chipman JG, Robertson DL and Simmons DL (1993) Prostaglandin $\mathrm{G} / \mathrm{H}$ synthase isoenzyme 2 expression in fibroblasts: regulation by dexamethasone, mitogens and oncogenes Archives of Biochemistry and Biophysics 306 169-177

Flower RJ (1974) Drugs which inhibit prostaglandin biosynthesis Pharmacological Reviews 26 33-67

Frazier LW and Yorio T (1992) Eicosanoids: their function in renal epithelia ion transport Proceedings of the Society for Experimental Biology and Medicine 201 229-243

Freed KA, Aitken MA, Brennecke SP and Rice GE (1995) Prostaglandin G/H synthase-1 messenger RNA relative abundance in human amnion, choriodecidua and placenta before, during and after spontaneous-onset labour at term Gynecologic and Obstetric Investigation 39 73-78

Frim DM, Emanuel RL, Robinson BG, Smas CM, Adler GK and Majzoub JA (1988) Characterization and gestational regulation of corticotropinreleasing hormone messenger RNA in human placenta Journal of Clinical Investigation 82 287-292

Fuchs AR, Fuchs F, Husslein P and Soloff MS (1984)1984 Oxytocin receptors in the human uterus during pregnancy and parturition American Journal of Obstetrics and Gynecology 150 734-741

Fuentes A, Spaziani EP and O'Brien WF (1996) The expression of cyclooxygenase-2 (COX-2) in amnion and decidua following spontaneous labor Prostaglandins 52 261-267

Germain AM, Smith J, Casey ML and MacDonald PC (1994) Human feta membrane contribution to the prevention of parturition: uterotonin degradation Journal of Clinical Endocrinology and Metabolism 78 $463-470$

Giannopoulos G, Jackson K and Tulchinsky D (1983) Specific glucocorticoid binding in human uterine tissues, placenta and fetal membranes Journal of Steroid Biochemistry 19 1375-1378

Giannoulias D, Patel FA, Lye SJ and Challis JRG (2002) Differential expression of prostaglandin synthase (type 1 and 2) and prostaglandin dehydrogenase in pregnant human myometrium Journal of Clinical Endocrinology and Metabolism 87 1345-1352 
Gibb W and Lavoie JC (1990) Effects of glucocorticoids on prostaglandin formation by human amnion Canadian Journal of Physiology and Pharmacology 68 671-676

Gibb W and Sun M (1996) Localization of prostaglandin H synthase type 2 protein and mRNA in term human fetal membranes and decidua Journal of Endocrinology 150 497-503

Gibb W, Lavoie JC and Roux JF (1978) 3ß-Hydroxysteroid dehydrogenase activity in human fetal membranes Steroids 32 365-372

Gomez R, Ghezzi F, Romero R, Munoz H, Tolosa JE and Rojas I (1995) Premature labor and intra-amniotic infection: clinical aspects and role of the cytokines in diagnosis and pathophysiology Clinical Perinatology 22 281-342

Goodwin VJ, Sato TA, Mitchell MD and Kellan JA (1998) Anti-inflammatory effects of interleukin-4, interleukin-10, and transforming growth factor- $\beta$ on human placental cells in vitro. American Journal of Reproductive Immunology 40 319-325

Goppelt-Struebe M (1995) Regulation of prostaglandin endoperoxide synthase (cyclooxygenase) isozyme expression Prostaglandins, Leukotrienes and Essential Fatty Acids 52 213-222

Goppelt-Struebe M (1997) Molecular mechanisms involved in the regulation of prostaglandin biosynthesis by glucocorticoids Biochemical Pharmacology 53 1389-1395

Grammatopoulos DK and Hillhouse EW (1999a) Basal and interleukin-1 $\beta$ stimulated prostaglandin production from cultured human myometrial cells: differential regulation by corticotropin-releasing hormone Journal of Clinical Endocrinology and Metabolism 84 2204-2211

Grammatopoulos DK and Hillhouse EW (1999b) Activation of protein kinase $\mathrm{C}$ by oxytocin inhibits the biological activity of the human myometrial corticotropin-releasing hormone receptor at term Endocrinology 140 585-594

*Grammatopoulos DK and Hillhouse EW (1999c) Role of corticotropinreleasing hormone in onset of labour Lancet 354 1546-1549

Gyomorey S, Lye SJ, Gibb W and Challis JRG (2000) Fetal-to-maternal progression of prostaglandin $\mathrm{H}_{2}$ synthase-2 expression in ovine intrauterine tissues during the course of labor Biology of Reproduction $62797-805$

Hahn EL, Clancy KD, Tai HH, Ricken JD, He LK and Gamelli RL (1998) Prostaglandin $E_{2}$ alterations during sepsis are partially mediated by endotoxin-induced inhibition of prostaglandin 15-hydroxydehydrogenase Journal of Trauma 44 777-781

Hansen HS (1976) 15-hydroxyprostaglandin dehydrogenase: a review Prostaglandins 12 647-679

Harper MJK, Bodkhe RR and Friedrichs WE (1980) Effect of endotoxin treatment on prostaglandin metabolism by rabbit uterus and oviduct Journal of Reproduction and Fertility 58 101-108

Harper MJK, Khodr GS and Valenzuela G (1983) Prostaglandin production by human term placentas in vitro. Prostaglandins, Leukotrienes and Medicine 11 121-129

Hertelendy F, Romero R, Molnar M, Todd H and Baldassare JJ (1993) Cytokine-initiated signal transduction in human myometrial cells American Journal of Reproductive Immunology 30 49-57

Hirst JJ, Teixeira FJ, Zakar T and Olson DM (1995a) Prostaglandin endoperoxide- $\mathrm{H}$ synthase- 1 and -2 messenger ribonucleic acid levels in human amnion with spontaneous labor onset Journal of Clinical Endocrinology and Metabolism 80 517-523

Hirst JJ, Teixeira FJ, Zakar T and Olson DM (1995b) Prostaglandin H synthase-2 expression increases in human gestational tissues with spontaneous labour onset Reproduction, Fertility and Development 7 633-637

Hofmann GE, Rao CV, Barrows GH and Sanfilippo JS (1983) Topography of human uterine prostaglandin $E$ and $F_{2 \alpha}$ receptors and their profiles during pathological states Journal of Clinical Endocrinology and Metabolism 57 360-366

Ikegami M, Jobe AH, Newnham J, Polk DH, Willett KE and Sly P (1997) Repetitive prenatal glucocorticoids improve lung function and decrease growth in preterm lambs American Journal of Respiratory and Critical Care Medicine 156 178-184

Inoue H, Kosaka T, Miyata A, Hara S, Yokoyama C, Nanayama T and Tanabe T (1995) Structure and expression of the human prostaglandin endoperoxide synthase 2 gene. In Advances in Prostaglandin, Thromboxane and Leukotriene Research pp 109-111 Eds B Samuelsson and R Paoletti. Raven Press, New York

Jana N, Vasishta K, Saha SC and Khunnu B (1995) Effect of bronchial asthma on the course of pregnancy, labour and perinatal outcome Journal of Obstetrics and Gynaecology 3 227-232

Johnston PC, Greer IA and Brooks AN (1996) The transfer of prostaglandin $E_{2}$ across ovine fetal membranes in vivo. Journal of Society for Gynecologic Investigation 3 303-308

Jones SA and Challis JRG (1990a) Effects of corticotropin-releasing hormone and adrenocorticotropin on prostaglandin output by human placenta and fetal membranes Gynecologic and Obstetric Investigation 29 165-168

Jones SA and Challis JRG (1990b) Steroid, corticotrophin-releasing hormone, ACTH and prostaglandin interactions in the amnion and placenta of early pregnancy in man Journal of Endocrinology 125 153-159

Karalis K, Goodwin G and Majzoub JA (1996) Cortisol blockade of progesterone: a possible molecular mechanism involved in the initiation of human labor Nature Medicine 2 556-560

*Karteris E, Grammatopoulos K, Randeva HS and Hillhouse EW (2001) The role of corticotropin-releasing hormone receptors in placenta and fetal membranes during human pregnancy Molecular Genetics and Metabolism 72 287-296

Keelan JA, Sato T and Mitchell MD (1997) Interleukin (IL)-6 and IL-8 production by human amnion: regulation by cytokines, growth factors, glucocorticoids, phorbol esters and bacterial lipopolysaccharide Biology of Reproduction 57 1438-1444

Keirse MJNC (1990) Eicosanoids in human pregnancy and parturition. In Eicosanoids and Reproduction pp 199-222 Ed. MD Mitchell. CRC Press, Boca Raton

Keirse MJNC (1993) Prostaglandins in preinduction cervical ripening. Metaanalysis of worldwide clinical experience Journal of Reproductive Medicine 38 89-100

Keirse MJNC and Turnbull AC (1975) Metabolism of prostaglandins within the pregnant uterus British Journal of Obstetrics and Gynaecology 82 887-893

Keirse MJNC and Turnbull AC (1976) The fetal membranes as a possible source of amniotic fluid prostaglandins British Journal of Obstetrics and Gynaecology 83 146-151

Keirse MJNC, Hicks BR and Turnbull AC (1976) Prostaglandin dehydrogenase in the placenta before and after the onset of labour British Journal of Obstetrics and Gynaecology 83 152-155

Keirse MJNC, Hicks BR, Kendall JZ and Mitchell MD (1978) Comparison of intrauterine prostaglandin metabolism during pregnancy in man, sheep and guinea pig European Journal of Obstetrics and Gynecology and Reproductive Biology 8 195-203

Keirse MJNC, Erwich JJHM and Klok G (1985) Increase in placental 15hydroxy prostaglandin dehydrogenase in the first half of human pregnancy Prostaglandins 30 131-140

Kitterman JA (1987) Arachidonic acid metabolites and control of breathing in the fetus and newborn Seminars in Perinatology 11 43-52

Kniss DA (1999) Cyclooxygenases in reproductive medicine and biology Journal of Society for Gynecologic Investigation 6 285-292

Korebrits C, Ramirez MM, Watson L, Brinkmann E, Bocking AD and Challis JRG (1998) Maternal corticotropin-releasing hormone is increased with impending preterm birth Journal of Clinical Endocrinology and Metabolism 83 1585-1591

Kredentser JV, Embree JE and McCoshen JA (1995) Prostaglandin $F_{2 a}$ output by amnion-chorion-decidua: relationship with labor and prostaglandin $\mathrm{E}_{2}$ concentration at the amniotic surface American Journal of Obstetrics and Gynecology 173 199-204

Krook M, Prozorovski V, Atrian S, Gonzalez-Duarte R and Jornvall $\mathbf{H}$ (1992) Short-chain dehydrogenases: proteolysis and chemical modification of prokaryotic $3 \alpha / 20 \beta$-hydroxysteroid, insect alcohol and human 15-hydroxyprostaglandin dehydrogenases European Journal of Biochemistry 209 233-239

Lamont RF, Anthony F, Myatt L, Booth L, Furr PM and Taylor-Robinson D (1990) Production of prostaglandin $E_{2}$ by human amnion in vitro in 
response to addition of media conditioned by microorganisms associated with chorioamnionitis and preterm labor American Journal of Obstetrics and Gynecology 162 819-825

Lee SC and Levine L (1975) Prostaglandin metabolism. II. Identification of two 15-hydroxyprostaglandin dehydrogenase types Journal of Biological Chemistry 250 548-552

Lennon C, Carlson MG, Nelson DM and Sadovsky Y (1999) In vitro modulation of the expression of 15-hydroxy-prostaglandin dehydrogenase by trophoblast differentiation American Journal of Obstetrics and Gynecology 180 690-695

Liggins GC (1968) Premature parturition after infusion of corticotrophin or cortisol into foetal lambs Journal of Endocrinology 42 323-329

Liggins GC (1977) Adrenocortical-related maturational events in the fetus American Journal of Obstetrics and Gynecology 126 931-941

Liggins GC and Thorburn GD (1994) Initiation of parturition. In Marshall's Physiology of Reproduction pp 863-1002 Ed. GE Lamming. Chapman and Hall, London

Liggins GC, Fairclough RJ, Grieves SH, Kendall JS and Knox BS (1973) The mechanism of initiation of parturition in the ewe Recent Progress in Hormone Research 29 111-159

Liggins GC, Forster CS, Grieves SA and Schwartz AL (1977) Control of parturition in man Biology of Reproduction 16 39-56

Linton EA, Perkins AV, Woods RJ, Eben F, Wolfe CD, Behan DP, Potter E, Vale WW and Lowry PJ (1993) Corticotropin releasing hormonebinding protein (CRH-BP) plasma levels decrease during the third trimester of normal human pregnancy Journal of Clinical Endocrinology and Metabolism 76 260-262

Lopez-Bernal A, Hansell DJ, Alexander S and Turnbull AC (1987a) Prostaglandin E production by amniotic cells in relation to term and preterm labour British Journal of Obstetrics and Gynaecology 94 864-869

Lopez-Bernal A, Hansell DJ, Alexander S and Turnbull AC (1987b) Steroid conversion and prostaglandin production by chorionic and decidual cells in relation to term and preterm labour British Journal of Obstetrics and Gynaecology 94 1052-1058

Lopez-Bernal A, Watson SP, Phaneuf S and Europe-Finner GN (1993) Biochemistry and physiology of preterm labour and delivery Balliere's Clinical Obstetrics and Gynaecology 7 523-552

Lumley J (1993) The epidemiology of preterm birth Balliere's Clinical Obstetrics and Gynaecology 7 477-498

Lundin-Schiller S and Mitchell MD (1990) The role of prostaglandins in human parturition Prostaglandins, Leukotrienes and Essential Fatty Acids 39 1-10

*Lye SJ, Ou CW, Teoh TG, Erb G, Stevens Y, Casper R, Patel FA and Challis JRG (1998) The molecular basis of labour and tocolysis Fetal and Maternal Medicine Review 10 121-136

McCoshen JA, Johnson KA, Dubin NH and Ghodgaonkar RB (1987) Prostaglandin $\mathrm{E}_{2}$ release on the fetal and maternal sides of the amnion and chorion-decidua before and after term labor American Journal of Obstetrics and Gynecology 156 173-178

McCoshen JA, Hoffman DR, Kredentser JV, Araneda C and Johnston JM (1990) The role of fetal membranes in regulating production, transport, and metabolism of prostaglandin $\mathrm{E}_{2}$ during labor American Journal of Obstetrics and Gynecology 163 1632-1640

MacDonald PC, Koga S and Casey ML (1991) Decidual activation in parturition: examination of amniotic fluid for mediators of the inflammatory response Annals New York Academy of Sciences 622 315-330

McLean M, Bisits A, Davies J, Woods R, Lowry P and Smith R (1995) A placental clock controlling the length of human pregnancy Nature Medicine $1460-463$

Matsuo M, Ensor CM and Tai HH (1996) Cloning and expression of the CDNA for mouse $\mathrm{NAD}^{+}$-dependent 15-hydroxyprostaglandin dehydrogenase Biochimica et Biophysica Acta 1309 21-24

Matsuo M, Ensor CM and Tai HH (1997) Characterisation of the genomic structure and promotor of the mouse $\mathrm{NAD}^{+}$-dependent 15-hydroxyprostaglandin dehydrogenase gene Biochemical and Biophysical Research Communications 235 582-586

Mercer BM, Goldenberg RL, Das A et al. (1996) The preterm prediction study: a clinical risk assessment system American Journal of Obstetrics and Gynecology 174 1885-1893
Mitchell BF and Challis JRG (1988) Estrogen and progesterone metabolism in human fetal membranes. In The Human Fetal Membranes: Structure and Function pp 5-28 Ed. BF Mitchell. Perinatology Press, New York

Mitchell BF, Rogers K and Wong S (1993) The dynamics of prostaglandin metabolism in human fetal membranes and decidua around the time of parturition Journal of Clinical Endocrinology and Metabolism 77 759-764

Mitchell MD (1984) The mechanism(s) of human parturition Journal of Developmental Physiology 6 107-118

Mitchell MD (1988) Sources of eicosanoids within the uterus during pregnancy. In The Onset of Labor, Cellular and Integrative Mechanisms pp 165-183 Eds D McNellis, JRG Challis and PC MacDonald. Perinatology Press, Ithaca

Mitchell MD, Bibby JG, Hicks BR and Turnbull AC (1978) Specific production of prostaglandin E by human amnion in vitro. Prostaglandins 15 377-382

Mitchell MD, Lytton FD and Varticovski L (1988) Paradoxical stimulation of both lipocortin and prostaglandin production in human amnion cells by dexamethasone Biochemical and Biophysical Research Communications 151 137-141

Mitchell MD, Edwin SS, Lundin-Schiller S, Silver RM, Smotkin D and Trautman MS (1993a) Mechanism of interleukin-1 $\beta$ stimulation of human amnion prostaglandin biosynthesis mediation via a novel inducible cyclooxygenase Placenta 14 615-625

Mitchell MD, Trautman MS and Dudley DJ (1993b) Immunoendocrinology of preterm labour and delivery Balliere's Clinical Obstetrics and Gynaecology 7 553-575

Mitchell MD, LaMarche S, Adamson S, Coulam C, Silver RM and Edwin SS (1994) Regulation of intrauterine prostaglandin biosynthesis interaction between protein kinase $\mathrm{C}$ and interleukin-1 $\beta$ Prostaglandins, Leukotrienes and Essential Fatty Acids 50 137-140

Mitchell MD, Goodwin V, Mesnage S and Keelan JA (2000) Cytokineinduced coordinate expression of enzymes of prostaglandin biosynthesis and metabolism: 15-hydroxyprostaglandin dehydrogenase Prostaglandins, Leukotrienes and Essential Fatty Acids 62 1-5

Molnar $\mathbf{M}$ and Hertelendy $\mathbf{F}$ (1990) $\mathrm{PGF}_{2 \alpha}$ and $\mathrm{PGE}_{2}$ binding to rat myometrium during gestation, parturition, and postpartum American Journal of Physiology 258 E740-E747

Molnar M, Rigo JJ, Romero R and Hertelendy F (1999) Oxytocin activates mitogen-activated protein kinase and upregulates cyclooxygenase-2 and prostaglandin production in human myometrial cells American Journal of Obstetrics and Gynecology 181 42-49

Moonen P, Klok G and Kerise MJNC (1984) Increase in concentrations of prostaglandin endoperoxide synthase and prostacyclin synthase in human myometrium in late pregnancy Prostaglandins 28 309-321

Moonen P, Klok G and Keirse MJ (1986) Distribution of prostaglandin endoperoxide synthase and prostacyclin synthase in the late pregnant uterus British Journal of Obstetrics and Gynaecology 93 255-259

Moore PK and Hoult JR (1978) Experimental hyperthyroidism in rats suppresses in vitro prostaglandin metabolism in lung and kidney Prostaglandins 16 335-349

Moore SD, Brodt-Eppley J, Cornelison LM, Burk SE, Slater DM and Myatt L (1999) Expression of prostaglandin $\mathrm{H}$ synthase isoforms in human myometrium at parturition American Journal of Obstetrics and Gynecology 180 103-109

Morrison JC (1990) Preterm birth: a puzzle worth solving Obstetrics and Gynecology 76 5S-12S

Myatt L and Moore SD (1994) Myometrium and preterm labour steroids and prostaglandins Seminars in Reproductive Endocrinology 12 298-313

Nakano J and Prancan AV (1973) Metabolic degradation of prostaglandin $E_{1}$ in the lung and kidney of rats in endotoxin shock Proceedings of the Society for Experimental Biology and Medicine 144 506-508

Nakla S, Skinner K, Mitchell BF and Challis JRG (1986) Changes in prostaglandin transfer across human fetal membranes obtained after spontaneous labor American Journal of Obstetrics and Gynecology 155 1337-1341

Novy MJ and Liggins GC (1980) Role of prostaglandins, prostacyclin, and thromboxanes in the physiologic control of the uterus and in parturition Seminars in Perinatology 4 45-66

Novy MJ and Walsh SW (1983) Dexamethasone and estradiol treatment in 
pregnant rhesus macaques: effects on gestational length, maternal plasma hormones, and fetal growth American Journal of Obstetrics and Gynecology 145 920-931

Okazaki T, Casey ML, Okita JR, MacDonald PC and Johnston JM (1981) Initiation of parturition. XII. Biosynthesis and metabolism of prostaglandins in human fetal membranes and uterine decidua American Journal of Obstetrics and Gynecology 139 373-381

Okita RT and Okita JR (1996) Prostaglandin-metabolizing enzymes during pregnancy characterization of $\mathrm{NAD}^{+}$-dependent prostaglandin dehydrogenase, carbonyl reductase, and cytochrome P450-dependent prostaglandin omega-hydroxylase Critical Reviews in Biochemistry and Molecular Biology 31 101-126

Olson DM, Skinner K and Challis JRG (1983) Prostaglandin output in relation to parturition by cells dispersed from human intrauterine tissues Journal of Clinical Endocrinology and Metabolism 57 694-699

Olson DM, Smieja Z, Zakar T, MacLeod EA, Walton J and Milne K (1991) Regulation of prostaglandin synthesis in the human amnion Reproduction, Fertility and Development 3 413-419

Olson DM, Mijovic JE and Sadowsky DW (1995) Control of human parturition Seminars in Perinatology 19 52-63

Ou CW, Chen ZQ, Qi S and Lye SJ (2000) Expression and regulation of the messenger ribonucleic acid encoding the prostaglandin $\mathrm{F}_{2 \alpha}$ receptor in the rat myometrium during pregnancy and labor American Journal of Obstetrics and Gynecology 182 919-925

Pace-Asciak CR and Smith WL (1983) Enzymes in the biosynthesis and catabolism of the eicosanoids, prostaglandins, thromboxanes, leukotrienes, and hydroxy fatty acids. In The Enzymes Vol. 16 pp 543-603 Ed. P Boyer. Academic Press, New York

Parkes DG and Eling TE (1975) The influence of environmental agents on prostaglandin biosynthesis and metabolism in the lung: inhibition of lung 15-hydroxyprostaglandin dehydrogenase by exposure of guinea pigs to 100 per cent oxygen at atmospheric pressure Biochemistry $\mathbf{1 4 6}$ 549-556

Patel FA, Clifton VL, Chwalisz K and Challis JRG (1999) Steroid regulation of prostaglandin dehydrogenase activity and expression in human term placenta and chorio-decidua in relation to labor Journal of Clinical Endocrinology and Metabolism 84 291-299

Perlow JH, Montgomery D, Morgan MA, Towers CV and Porto M (1992) Severity of asthma and perinatal outcome American Journal of Obstetrics and Gynecology 167 963-967

Petraglia F, Florio P, Nappi C and Genazzani AR (1996) Peptide signaling in human placenta and membranes: autocrine, paracrine and endocrine mechanisms Endocrine Reviews 17 156-186

Pichaud F, Roux S, Frendo JL, Delage-Mourroux R, Maclouf J, de Vernejoul MC, Moukhtar MS and Jullienne A (1997) 1,25-Dihydroxyvitamin D3 induces $\mathrm{NAD}^{+}$-dependent 15-hydroxyprostaglandin dehydrogenase in human neonatal monocytes Blood 89 2105-2112

Pisarello JB, Flores D and Jackson RM (1997) Effects of hypoxia and hyperoxia on lung prostaglandin $\mathrm{E}_{1}$ metabolism American Journal of Medical Science 313 147-152

Pomini F, Caruso A and Challis JRG (1999) Interleukin-10 modifies the effects of interleukin- $1 \beta$ and tumor necrosis factor- $\alpha$ on the activity and expression of prostaglandin $\mathrm{H}$ synthase- 2 and the $\mathrm{NAD}^{+}$-dependent 15 hydroxyprostaglandin dehydrogenase in cultured term human villous trophoblast and chorion trophoblast cells Journal of Clinical Endocrinology and Metabolism 84 4645-4651

Potestio FA, Zakar T and Olson DM (1988) Glucocorticoids stimulate prostaglandin synthesis in human amnion cells by a receptor-mediated mechanism Journal of Clinical Endocrinology and Metabolism 67 1205-1210

Ramwell PW and Shaw JE (1970) Biological significance of the prostaglandins Recent Progress in Hormone Research 26 139-187

Rankin JG (1976) A role for prostaglandins in the regulation of the placental blood flows Prostaglandins 11 343-353

Reddi K, Deppe WM and Norman RJ (1990) Increased and intermittent prostaglandin release from amnion detected by a new superfusion technique for full thickness fetal membrane Prostaglandins 39 $601-610$

Reinisch JM, Simon NG, Karow WG and Gandelman R (1978) Prenatal exposure to prednisone in humans and animals retards intrauterine growth Science 202 436-438

Riley SC, Dupont E, Walton JC, Luu-The V, Labrie F, Pelletier G and Challis JRG (1992) Immunohistochemical localization of 3ß-hydroxy-5-enesteroid dehydrogenase $/ \Delta^{5} \rightarrow \Delta^{4}$ isomerase in human placenta and fetal membranes throughout gestation Journal of Clinical Endocrinology and Metabolism 75 956-961

Ristimaki A, Garfinkel S, Wessendorf J, Maciag T and Hla T (1994) Induction of cyclooxygenase- 2 by interleukin-1 $\alpha$ : evidence for posttranscriptional regulation Journal of Biological Chemistry 26911 769-11 775

Ritchie DM, Hahn DW and McGuire JL (1984) Smooth muscle contraction as a model to study the mediator role of endogenous lipoxygenase products of arachidonic acid Life Sciences 34 509-513

Romero R, Durum S, Dinarello C, Oyarzun E, Hobbins JC and Mitchell MD (1989a) Interleukin-1 stimulates prostaglandin biosynthesis by human amnion Prostaglandins 37 13-22

Romero R, Manogue KR, Mitchell MD, Wu YK, Oyarzun E, Hobbins JC and Cerami A (1989b) Infection and labor. IV. Cachectin-tumor necrosis factor in the amniotic fluid of women with intraamniotic infection and preterm labor American Journal of Obstetrics and Gynecology 161 336-341

Romero R, Wu YK, Oyarzun E, Hobbins JC and Mitchell M (1989c) A potential role for epidermal growth factor/alpha-transforming growth factor in human parturition European Journal of Obstetrics and Gynecology and Reproductive Biology 33 55-60

Romero R, Mazor M, Manogue KR, Oyarzun E and Cerami A (1991) Human decidua: a source of cachectin-tumor necrosis factor European Journal of Obstetrics and Gynecology and Reproductive Biology 41 123-127

Rose MP, Myatt L and Elder MG (1990) Pathways of arachidonic acid metabolism in human amnion cells at term Prostaglandins, Leukotrienes and Essential Fatty Acids 39 303-309

Roseblade CK, Sullivan MH, Khan H, Lumb MR and Elder MG (1990) Limited transfer of prostaglandin $E_{2}$ across the fetal membrane before and after labor Acta Obstetricia et Gynecologica Scandinavica 69 399-403

Sakuma S, Fujimoto Y, Hikita E, Okano Y, Yamamoto I and Fujita T (1990) Effects of metal ions on 15-hydroxy prostaglandin dehydrogenase activity in rabbit kidney cortex Prostaglandins 40 507-514

Sakuma S, Fujimoto Y, Miyata Y, Ohno M, Nishida H and Fujita T (1996) Effects of $\mathrm{Fe}^{2+}, \mathrm{Zn}^{2+}, \mathrm{Cu}^{2+}$ and $\mathrm{Se}^{4+}$ on the synthesis and catabolism of prostaglandins in rabbit gastric antral mucosa Prostaglandins, Leukotrienes and Essential Fatty Acids 54 193-197

Sangha RK, Walton JC, Ensor CM, Tai HH and Challis JRG (1994) Immunohistochemical localization, messenger ribonucleic acid abundance, and activity of 15-hydroxyprostaglandin dehydrogenase in placenta and fetal membranes during term and preterm labor Journal of Clinical Endocrinology and Metabolism 78 982-989

Sastry BV, Hemontolor ME, Chance MB and Johnson RF (1997) Dual messenger function for prostaglandin $\mathrm{E}_{2}\left(\mathrm{PGE}_{2}\right)$ in human placenta Cellular and Molecular Biology 43 417-424

Sastry BV, Hemontolor ME and Olenick M (1999) Prostaglandin $E_{2}$ in human placenta: its vascular effects and activation of prostaglandin $E_{2}$ formation by nicotine and cotinine Pharmacology 58 70-86

Satoh K, Yasumizu T, Kawai A, Ozaki A, Wu T, Kinoshita K and Sakamoto S (1981) In vitro production of prostaglandin E, F, and 6-keto prostaglandin $\mathrm{F}_{1 \alpha}$ by human pregnant uterus, decidua and amnion Prostaglandins and Medicine 6 359-368

Saunders-Kirkwood K, Cates JA and Roslyn JJ (1993) Prostaglandin $E_{2}$ stimulates ion transport in prairie dog gallbladder Digestive Diseases and Sciences 38 167-172

Schaefers HJ and Goppelt-Struebe M (1996) Interference of corticosteroids with prostaglandin $\mathrm{E}_{2}$ synthesis at the level of cyclooxygenase-2 mRNA expression in kidney cells Biochemical Pharmacology 52 1415-1421

Schatz M, Zeiger RS and Hoffman CP (1990) Intrauterine growth is related to gestational pulmonary function in pregnant asthmatic women KaiserPermanente Asthma and Pregnancy Study Group Chest 98 389-392

Seckl JR and Meaney MJ (1993) Early life events and later development of ischaemic heart disease Lancet $\mathbf{3 4 2} 1236$ 
Seckl JR and Miller WL (1997) How safe is long-term prenatal glucocorticoid treatment? Journal of the American Medical Association 277 1077

Senior J, Marshall K, Sangha R, Baxter GS and Clayton JK (1991) In vitro characterization of prostanoid EP-receptor in the non-pregnant human myometrium British Journal of Pharmacology 102 747-753

Senior J, Sangha RK, Baxter GS, Marshall K and Clayton JK (1992) In vitro characterization of prostanoid FP-, DP, IP- and TP-receptors on the nonpregnant human myometrium British Journal of Pharmacology 107 215-221

Senior J, Marshall K, Sangha R and Clayton JK (1993) In vitro characterization of prostanoid receptors on human myometrium at term pregnancy British Journal of Pharmacology 108 501-506

Skinner K and Challis JRG (1985) Changes in the synthesis and metabolism of prostaglandins by human fetal membranes and decidua at labor American Journal of Obstetrics and Gynecology 151 519-523

Slater DM, Berger LC, Newton R, Moore GE and Bennett PR (1995) Expression of cyclooxygenase types 1 and 2 in human fetal membranes at term American Journal of Obstetrics and Gynecology 172 77-82

Slater D, Allport V and Bennett P (1998) Changes in the expression of the type-2 but not the type-1 cyclo-oxygenase enzyme in chorion-decidua with the onset of labour British Journal of Obstetrics and Gynaecology $105745-748$

Smieja Z, Zakar T and Olson DM (1993) Stimulation of cultured amnion cell prostaglandin endoperoxide $\mathrm{H}$ synthase activity by glucocorticoids and phorbol ester American Journal of Obstetrics and Gynecology 169 653-661

Smith WL, Garavito RM and DeWitt DL (1996) Prostaglandin endoperoxide $\mathrm{H}$ synthases (cyclooxygenases)-1 and -2 Journal of Biological Chemistry 27133 157-33 160

So T (1993) The role of matrix metalloproteinases for premature rupture of the membranes Nippon Sanka Fujinka Gakkai Zasshi 45 227-233

Soloff MS, Jeng YJ, Copland JA, Strakova Z and Hoare S (2000) Signal pathways mediating oxytocin stimulation of prostaglandin synthesis in select target cells Experimental Physiology 85 51S-58S

Sparey C, Robson SC, Bailey J, Lyall F and Europe-Finner GN (1999) The differential expression of myometrial connexin-43, cyclooxygenase-1 and -2 , and $\mathrm{G}_{\mathrm{s}} \alpha$ proteins in the upper and lower segments of the human uterus during pregnancy and labor Journal of Clinical Endocrinology and Metabolism 84 1705-1710

Spaziani EP, O'Brien WF, Benoit RB and Gould SF (2000) Corticotrophinreleasing hormone induces the expression of the prostaglandin E2 receptor subtype EP1 in amnion WISH cells Biology of Reproduction 62 $23-26$

Stevens MY, Challis JRG and Lye SJ (1998) Corticotropin-releasing hormone receptor subtype 1 is significantly upregulated at the time of labor in the human myometrium Journal of Clinical Endocrinology and Metabolism 83 4107-4115

Strickland DM and Mitchell MD (1987) Stimulation of prostaglandin E production in superfused human amnion by human amniotic fluid Gynecologic and Obstetric Investigation 23 23-27

Stubblefield PG (1993) Causes and prevention of premature birth: an overview. In Preterm Birth Causes, Prevention and Management 2nd Edn pp 3-41 Eds A Fuchs, F Fuchs and PG Stubblefield. McGraw Hill Inc., New York

Sullivan MH, Roseblade CK and Elder MG (1991) Metabolism of prostaglandin $\mathrm{E}_{2}$ on the fetal and maternal sides of intact fetal membranes Acta Obstetricia et Gynecologica Scandinavica 70 425-427

Sullivan MH, Roseblade CK, Rendell NB, Taylor GW and Elder MG (1992) Metabolism of prostaglandins $E_{2}$ and $F_{2 \alpha}$ by human fetal membranes Biochimica et Biophysica Acta 1123 342-346

Sullivan MH, Kent AS, Lumb MR, Roseblade CK and Elder MG (1993) The amnion produces little of the prostaglandin $\mathrm{E}_{2}$ detected on the decidual side of human fetal membranes Acta Obstetricia et Gynecologica Scandinavica 72 520-525

Sun M, Ramirez M, Challis JRG and Gibb W (1996) Immunohistochemical localization of the glucocorticoid receptor in human fetal membranes and decidua at term and preterm delivery Journal of Endocrinology 149 $243-248$
Tahara M, Tasaka K, Masumoto N, Adachi K, Adachi H, Ikebuchi Y Kurachi $\mathbf{H}$ and Miyake A (1995) Expression of messenger ribonucleic acid for epidermal growth factor (EGF), transforming growth factoralpha (TGF $\alpha$ ), and EGF receptor in human amnion cells: possible role of TGF $\alpha$ in prostaglandin $E_{2}$ synthesis and cell proliferation Journal of Clinical Endocrinology and Metabolism $80138-146$

Tai HH and Hollander CS (1976) Kinetic evidence of a distinct regulatory site on 15-hydroxyprostaglandin dehydrogenase. In Advances in Prostaglandin and Thromboxane Research Vol. 1 pp 171-175 Eds B Samuelsson and R Paoletti. Raven Press, New York

Tai HH, Tai CL and Hollander CS (1974) Regulation of prostaglandin metabolism: inhibition of 15-hydroxyprostaglandin dehydrogenase by thryoid hormones Biochemical and Biophysical Research Communications 57 457-462

Tazawa R, Xu XM, Wu KK and Wang LH (1994) Characterization of the genomic structure, chromosomal location and promoter of human prostaglandin $\mathrm{H}$ synthase-2 gene Biochemical and Biophysical Research Communications 203 190-199

Teixeira FJ, Zakar T, Hirst J, Guo F, Machin G and Olson DM (1993) Prostaglandin endoperoxide $\mathrm{H}$ synthase (PGHS) activity increases with gestation and labour in human amnion Journal of Lipid Mediators 6 515-523

Teixeira FJ, Zakar T, Hirst J, Gua F, Sadowsky DW, Machini G, Demianczuk N, Resch B and Olson DM (1994) Prostaglandin endoperoxide- $\mathrm{H}$ synthase (PGHS) activity and immunoreactive PGHS-1 and PGHS-2 levels in human amnion throughout gestation, at term, and during labor Journal of Clinical Endocrinology and Metabolism 78 1396-1402

Thorburn GD (1992) The placenta, PGE 2 , and parturition Early Human Development 29 63-73

Trautman MS, Edwin SS, Collmer D, Dudley DJ, Simmons D and Mitchell MD (1996) Prostaglandin H synthase-2 in human gestational tissues: regulation in amnion Placenta 17 239-245

Tsuboi K, Sugimoto Y, Iwane A, Yamamoto K, Yamamoto S and Ichikawa A (2000) Uterine expression of prostaglandin $\mathrm{H}_{2}$ synthase in late pregnancy and during parturition in prostaglandin $\mathrm{F}$ receptor-deficient mice Endocrinology 141 315-324

Ulmsten U, Wingerup L, Belfrage P, Ekman G and Wiqvist N (1982) Intracervical application of prostaglandin gel for induction of term labor Obstetrics and Gynecology 59 336-339

Uno H, Lohmiller L, Thieme C, Kemnitz JW, Engle MJ, Roecker EB and Farrell PM (1990) Brain damage induced by prenatal exposure to dexamethasone in fetal rhesus macaques. I. Hippocampus Developmental Brain Research 53 157-167

Vader CR, Mathias MM and Schatte CL (1981) Pulmonary prostaglandin metabolism during normobaric hyperoxia Prostaglandins and Medicine 6 101-110

Vadillo-Ortega F, Beltran J, Mateo H and Monzon F (1994) Phospholipase $\mathrm{A}_{2}$ and premature membrane rupture Ginecologia y Obstetricia de Mexico 62 143-145

van Meir CA, Sangha RK, Walton JC, Matthews SG, Keirse MJNC and Challis JRG (1996) Immunoreactive 15-hydroxyprostaglandin dehydrogenase $(\mathrm{PGDH})$ is reduced in fetal membranes from patients at preterm delivery in the presence of infection Placenta 17 291-297

van Meir CA, Matthews SG, Keirse MJNC, Ramirez MM, Bocking A and Challis JRG (1997a) 15-Hydroxyprostaglandin dehydrogenase $(\mathrm{PGDH})$ implications in preterm labor with and without ascending infection Journal of Clinical Endocrinology and Metabolism 82 969-976

van Meir CA, Ramirez MM, Matthews SG, Calder AA, Keirse MJNC and Challis JRG (1997b) Chorionic prostaglandin catabolism is decreased in the lower uterine segment with term labour Placenta 18 109-114

Villar J, Ezcurra EJ, de la Fuente VG and Canpodonico L (1994) Pre-term delivery syndrome: the unmet need Research and Clinical Forums $\mathbf{1 6}$ 9-33

Wang LH, Hajibeigi A, Xu XM, Loose-Mitchell D and Wu KK (1993 Characterization of the promoter of human prostaglandin $\mathrm{H}$ synthase-1 gene Biochemical and Biophysical Research Communications 190 406-411 
Warrick C, Skinner K, Mitchell BF and Challis JRG (1985) Relation between cyclic adenosine monophosphate and prostaglandin output by dispersed cells from human amnion and decidua American Journal of Obstetrics and Gynecology 153 66-71

Weisbart M and Huntley FM (1997) The presence of cortisol receptors in the human amnion Journal of Steroid Biochemistry and Molecular Biology 63 339-344

*Whittle WL, Holloway AC, Lye SJ, Gibb W and Challis JRG (2000a) Prostaglandin production at the onset of ovine parturition is regulated by both estrogen-independent and estrogen-dependent pathways Endocrinology 141 3783-3791

Whittle WL, Gibb W and Challis JRG (2000b) The characterization of human amnion epithelial and mesenchymal cells: the cellular expression, activity and glucocorticoid regulation of prostaglandin output Placenta 21 394-401

Wikland M, Lindblom B and Wiqvist N (1984) Myometrial response to prostaglandins during labor Gynecologic and Obstetric Investigation 17 131-138

Wiqvist N, Lindblom B, Wikland M and Wilhelmsson L (1983) Prostaglandins and uterine contactility Acta Obstetricia et Gynecologica Scandinavica Supplement $11323-29$

Word RA, Kamm KE and Casey ML (1992) Contractile effects of prostaglandins, oxytocin, and endothelin-1 in human myometrium in vitro: refractoriness of myometrial tissue of pregnant women to prostaglandins $\mathrm{E}_{2}$ and $\mathrm{F}_{2 \alpha}$ Journal of Clinical Endocrinology and Metabolism 75 $1027-1032$

Wu WX, Ma XH, Smith GC, Mecenas CA, Koenen SV and Nathanielsz PW (2000) Prostaglandin dehydrogenase mRNA in baboon intrauterine tissues in late gestation and spontaneous labor American Journal of Physiology 279 R1082-R1090

Xu P, Alfaidy N and Challis JRG (2002) Expression of matrix metalloproteinases (MMP)-2 and MMP-9 in human placenta and fetal membranes in relation to preterm and term labor Journal of Clinical Endocrinology and Metabolism 87 1353-1361

Xue S, Brockman DE, Slater DM and Myatt L (1995) Interleukin-1 $\beta$ induces the synthesis and activity of cytosolic phospholipase $A_{2}$ and the release of prostaglandin $\mathrm{E}_{2}$ in human amnion-derived WISH cells Prostaglandins 49 351-369

Xue S, Slater DM, Bennett PR and Myatt L (1996) Induction of both cytosolic phospholipase $\mathrm{A}_{2}$ and prostaglandin $\mathrm{H}$ synthase-2 by interleukin-1 $\beta$ in WISH cells is inhibited by dexamethasone Prostaglandins 51 107-124

Yeshaya A, Orvieto R, Ben-Shem E, Dekel A, Peleg D, Dicker D and BenRafael Z (1996) Uterine activity after betamethasone administration for the enhancement of fetal lung maturation European Journal of Obstetrics and Gynecology and Reproductive Biology 67 139-141

Zakar T and Olson DM (1989) Dexamethasone stimulates arachidonic acid conversion to prostaglandin $E_{2}$ in human amnion cells Journal of Developmental Physiology 12 269-272

Zeeman GG, Khan-Dawood FS and Dawood MY (1997) Oxytocin and its receptor in pregnancy and parturition: current concepts and clinical implications Obstetrics and Gynecology 89 873-883

Zuo J, Lei ZM, Rao CV, Pietrantoni M and Cook VD (1994) Differential cyclooxygenase- 1 and -2 gene expression in human myometria from preterm and term deliveries Journal of Clinical Endocrinology and Metabolism 79 894-899 